Journal of Advanced Research in Fluid Mechanics and Thermal Sciences

\title{
Modeling of Loop Heat Pipe Thermal Performance
}

\author{
Inès Gabsi ${ }^{1}$, Samah Maalej ${ }^{1}$, Mohamed Chaker Zaghdoudi ${ }^{1, *}$ \\ 1 University of Carthage, Institut National des Sciences Appliquées et de Technologie (INSAT), Laboratoire Matériaux, Mesures et Applications \\ (MMA) LR11ES25, Centre Urbain Nord, BP N676, 1080 Tunis, Tunisia
}

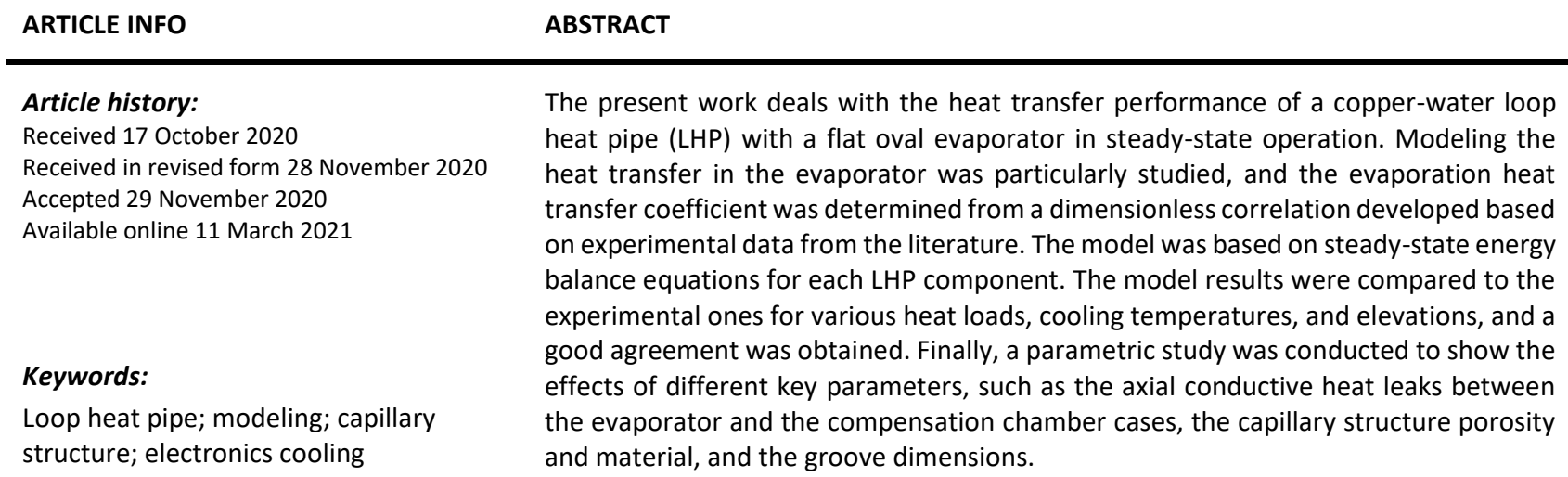

\section{Introduction}

Loop Heat Pipes (LHPs) are considered to be high heat transfer capacity passive devices that can operate at adverse tilts in the gravity field, and they can transfer heat over long distances. Due to the capillary structure in the evaporator and the compensation chamber, the LHPs possess a high capacity of pumping, and they could be solutions for thermal management in aerospace and avionic applications $[1,2]$

The design features and the operational characteristics of LHPs have attracted extensive interest from researchers both through experimental tests or theoretical studies. Experiments allow the classification of the LHPs into cylindrical and flat ones according to the evaporator shape. As the heat sources to be cooled have flat surfaces, LHPs with flat evaporators could fit most of them. The flat evaporators can be disk-shaped, rectangular, square, or flat-oval ones. The cylindrical evaporators could meet the flat heat source by adding flat saddles. The flat evaporators present many advantages, among which we can distinguish mainly the decrease in the thermal resistance and the weight of the evaporator; However, they also present drawbacks since the flat surface can be deformed under high vapor pressure if the heat source temperature increases accidentally. Therefore, flat evaporators should operate with vapor pressures that do not exceed the ambient pressure; otherwise, the

\footnotetext{
* Corresponding author.

E-mail address: chaker.zaghdoudi@insat.rnu.tn
} 
evaporator thickness must be increased. This condition on the vapor pressure limits the choice of the working fluids and the range of the operating temperatures.

The location of the compensation chamber plays a crucial role in the design of the flat evaporator, and thus two kinds of technologies were developed. In the first technology, the compensation chamber is located on the side opposite to the surface being heated so that the liquid flow in the capillary wick is directed towards the heated area. They are referred to as evaporators with Opposite Side to the Compensation Chamber (OS-CC) [3-17]. Singh et al., [3] investigated a copper-water LHP with a flat disk evaporator used for thermal control of computer microprocessors. They also examined the start-up reliability, the effect of the wick characteristics, and the effect of noncondensable gas on the thermal performance [4-6]. Celata et al., [7] carried out a thorough experimental investigation on a copper water LHP with a flat disk evaporator. Li et al., [8] reported on a copper-water compact LHP with a flat, square evaporator. The maximum heat load reached 450 $\mathrm{W}$ when the case temperature is below $100^{\circ} \mathrm{C}$. Adoni et al., [9] developed an ammonia LHP with a flat evaporator. The influence of the thermal conductance between the heater plate and the compensation chamber on the operating temperature of the LHP was investigated. Liu et al., [10] carried out experimental studies on the operational characteristics of LHP with a flat evaporator by investigating the impact of different working fluids, namely methanol and acetone. Nguyen et al., [11] designed a circular flat evaporator for cooling electronic devices and studied the effect of the orientation of the elevation and direction of the evaporator on heat transfer performance. Joung et al., [12] developed an LHP with a flat evaporator using a specially devised vapor-liquid separator and investigated its transient response. Wang et al., [13] reported on the LHP that utilizes two primary biporous wicks to reduce the impact of the leak on the compensation chamber. Xu et al., [14] investigated the heat performance of a flat copper water LHP with three fill charge inventories. He et al., [15] proposed a new flat evaporator structure (with OS-CC) with a strengthened ribbed plate on the side of the heating surface to surmount the distortion of the existing flat evaporator. Anand et al., [16] conducted a series of experiments to investigate the effect of different working fluids on the thermal behavior of a miniature LHP with a flat evaporator with OS-CC. Zhang et al., [17] developed a 3D model of an LHP with a carbon fiber capillary wick to study the steady-state inside the LHP and the effect of heat insulation layers on the heat leakage reduction in the LHP.

In the second technology, the liquid flow is directed along the evaporator wall [18-28]. They are referred to as evaporators with Aside Compensation Chamber (AS-CC). Singh et al., [18] designed and tested an LHP having a rectangular evaporator with a small thickness so that it can be used in compact electronic devices. Joung et al., [19] conducted a series of experiments to study the operating characteristics of an LHP using a thin planar bifacial evaporator with a bifacial wick structure for different fluid inventories. Its operating characteristics at transient and steady-state were examined [20]. Maydanik et al., [21] developed a compact copper-water LHP with a flat oval evaporator. The LHP was tested in a horizontal position, and the maximum heat load reached $1174 \mathrm{~W}$. Becker et al., [22] fabricated a copper-water LHP with a flat oval evaporator and tested it for different LHP orientations. Zhang et al., [23] conducted a series of experiments to investigate the effect of temperature oscillation on start-up behavior and thermal performance in an LHP with a flat evaporator. Wang et al., [24] fabricated a copper-water LHP with a thin flat evaporator. The LHP was tested in different condenser locations and operating orientations. Choi et al., [25] fabricated an LHP with sintered porous wicks used for the thermal management of high-power density desktop computers. Chernysheva et al., [26] studied the effect of the orientation in the gravity field, the sink temperature, and the ambient temperature on the LHP thermal performance. Maydanik et al., [27] developed a copper acetone LHP with a flat evaporator. The effect of the different orientations in the gravity field and heat sink temperature on the operating characteristics was investigated. Odagiri 
and Nagano [28] developed a steady-state model of an LHP that includes liquid-vapor interface behaviors. The main research studies on OS-CC and AS-CC technologies are listed in Table 1 and Table 2.

Table 1

Summary of studies on LHPs having a flat evaporator with opposite side compensation chamber (OS-CC)

\begin{tabular}{|c|c|c|c|c|c|c|c|c|c|}
\hline Year & Author & $\begin{array}{l}\text { Evapor } \\
\text { ator } \\
\text { shape }\end{array}$ & $\begin{array}{l}\text { Evaporator } \\
\text { dimensions }\end{array}$ & $\begin{array}{l}\text { Source } \\
\text { area }\end{array}$ & $\begin{array}{l}\text { Housing } \\
\text { material }\end{array}$ & $\begin{array}{l}\text { Wick } \\
\text { material }\end{array}$ & $\begin{array}{l}\text { Working } \\
\text { fluid }\end{array}$ & $\begin{array}{l}\text { Max. } \\
\text { heat load }\end{array}$ & $\begin{array}{l}\text { Max. } \\
\text { evaporator } \\
\text { temp. }\end{array}$ \\
\hline 2007 & $\begin{array}{l}\text { Singh et } \\
\text { al., [3] }\end{array}$ & $\begin{array}{l}\text { Flat } \\
\text { disk }\end{array}$ & $\begin{array}{l}\mathrm{D}=30 \mathrm{~mm} \\
\mathrm{t}=10 \mathrm{~mm}\end{array}$ & $\begin{array}{l}7.1 \\
\mathrm{~cm}^{2}\end{array}$ & Copper & Nickel & Water & $70 w$ & $100^{\circ} \mathrm{C}$ \\
\hline 2008 & $\begin{array}{l}\text { Singh et } \\
\text { al., [4] }\end{array}$ & $\begin{array}{l}\text { Flat } \\
\text { disk }\end{array}$ & $\begin{array}{l}\mathrm{D}=30 \mathrm{~mm} \\
\mathrm{t}=10 \mathrm{~mm}\end{array}$ & $\begin{array}{l}25 \times \\
25 \\
\mathrm{~mm}^{2}\end{array}$ & Copper & Nickel & Water & $70 w$ & $100^{\circ} \mathrm{C}$ \\
\hline 2009 & $\begin{array}{l}\text { Singh et } \\
\text { al., [5] }\end{array}$ & $\begin{array}{l}\text { Flat } \\
\text { disk }\end{array}$ & $\begin{array}{l}\mathrm{D}=30 \mathrm{~mm} \\
\mathrm{t}=10 \mathrm{~mm}\end{array}$ & $\begin{array}{l}25 \times \\
15 \\
\mathrm{~mm}^{2}\end{array}$ & Copper & Copper & Water & $60 \mathrm{~W}$ & $\begin{array}{l}\text { Not } \\
\text { indicated }\end{array}$ \\
\hline 2010 & $\begin{array}{l}\text { Singh et } \\
\text { al., [6] }\end{array}$ & $\begin{array}{l}\text { Flat } \\
\text { disk }\end{array}$ & $\begin{array}{l}\mathrm{D}=30 \mathrm{~mm} \\
\mathrm{t}=10 \mathrm{~mm}\end{array}$ & $\begin{array}{l}\mathrm{D}=30 \\
\mathrm{~mm}\end{array}$ & Copper & Copper & Water & $70 w$ & $100^{\circ} \mathrm{C}$ \\
\hline 2010 & $\begin{array}{l}\text { Celata et } \\
\text { al., [7] }\end{array}$ & $\begin{array}{l}\text { Flat } \\
\text { disk }\end{array}$ & $\begin{array}{l}D=50 \mathrm{~mm} \\
\mathrm{t}=13 \mathrm{~mm}\end{array}$ & $\begin{array}{l}\mathrm{D}=48 \\
\mathrm{~mm}\end{array}$ & Copper & $\begin{array}{l}\text { Stainless } \\
\text { steel }\end{array}$ & Water & $75 \mathrm{~W}$ & $150^{\circ} \mathrm{C}$ \\
\hline 2010 & $\begin{array}{l}\text { Li et al., } \\
\text { [8] }\end{array}$ & Square & $\begin{array}{l}\mathrm{W}=30 \mathrm{~mm} \\
\mathrm{~L}=30 \mathrm{~mm} \\
\mathrm{t}=15 \mathrm{~mm}\end{array}$ & $\begin{array}{l}25 \times \\
25 \\
\mathrm{~mm}^{2}\end{array}$ & Copper & Copper & Water & $600 \mathrm{~W}$ & $120^{\circ} \mathrm{C}$ \\
\hline 2010 & $\begin{array}{l}\text { Adoni et } \\
\text { al., [9] }\end{array}$ & $\begin{array}{l}\text { Flat } \\
\text { disk }\end{array}$ & $\begin{array}{l}D=150 \\
\mathrm{~mm} \\
\mathrm{t}=5 \mathrm{~mm}\end{array}$ & $\begin{array}{l}\mathrm{D}= \\
128 \\
\mathrm{~mm}\end{array}$ & $\begin{array}{l}\text { Aluminu } \\
\mathrm{m}- \\
\text { Stainless } \\
\text { steel }\end{array}$ & Nickel & $\begin{array}{l}\text { Ammoni } \\
\text { a }\end{array}$ & $300 \mathrm{~W}$ & $43^{\circ} \mathrm{C}$ \\
\hline 2011 & $\begin{array}{l}\text { Liu et al., } \\
{[10]}\end{array}$ & $\begin{array}{l}\text { Rectan } \\
\text { gular }\end{array}$ & $\begin{array}{l}\mathrm{W}=30 \mathrm{~mm} \\
\mathrm{~L}=40 \mathrm{~mm} \\
\mathrm{t}=1.5 \mathrm{~mm}\end{array}$ & $\begin{array}{l}40 \times \\
30 \\
\mathrm{~mm}^{2}\end{array}$ & Copper & $\begin{array}{l}\text { Stainless } \\
\text { steel }\end{array}$ & $\begin{array}{l}\text { Methano } \\
\text { I } \\
\text { Acetone }\end{array}$ & $60 \mathrm{~W}$ & $\begin{array}{l}55^{\circ} \mathrm{C} \\
52^{\circ} \mathrm{C}\end{array}$ \\
\hline 2012 & $\begin{array}{l}\text { Nguyen } \\
\text { et al., } \\
{[11]}\end{array}$ & $\begin{array}{l}\text { Flat } \\
\text { disk }\end{array}$ & $\begin{array}{l}\mathrm{D}=41 \mathrm{~mm} \\
\mathrm{t}=15 \mathrm{~mm}\end{array}$ & $\begin{array}{l}30 \times \\
30 \\
\mathrm{~mm}^{2}\end{array}$ & $\begin{array}{l}\text { Stainless } \\
\text { steel }\end{array}$ & Copper & Water & $140 \mathrm{~W}$ & $65^{\circ} \mathrm{C}$ \\
\hline 2013 & $\begin{array}{l}\text { Joung et } \\
\text { al., [12] }\end{array}$ & $\begin{array}{l}\text { Rectan } \\
\text { gular }\end{array}$ & $\begin{array}{l}\mathrm{W}=52 \mathrm{~mm} \\
\mathrm{~L}=56.40 \\
\mathrm{~mm} \\
\mathrm{t}=5 \mathrm{~mm}\end{array}$ & $\begin{array}{l}52 \times \\
52 \\
\mathrm{~mm}^{2}\end{array}$ & $\begin{array}{l}\text { Stainless } \\
\text { Steel }\end{array}$ & $\begin{array}{l}\text { Stainless } \\
\text { Steel }\end{array}$ & $\begin{array}{l}\text { Methano } \\
\text { I }\end{array}$ & $140 \mathrm{~W}$ & $120^{\circ} \mathrm{C}$ \\
\hline 2015 & $\begin{array}{l}\text { Wang et } \\
\text { al., [13] }\end{array}$ & $\begin{array}{l}\text { Flat } \\
\text { disk }\end{array}$ & $\begin{array}{l}\mathrm{D}=37.6 \\
\mathrm{~mm} \\
\mathrm{t}=4.3 \mathrm{~mm}\end{array}$ & $\begin{array}{l}\mathrm{D}=36 \\
\mathrm{~mm}\end{array}$ & Copper & Nickel & $\begin{array}{l}\text { Methano } \\
\text { I }\end{array}$ & $\begin{array}{l}270 \mathrm{~W}(+ \\
\left.90^{\circ}\right) \\
210 \mathrm{~W}(+ \\
\left.10^{\circ}\right)\end{array}$ & $90^{\circ} \mathrm{C}$ \\
\hline 2017 & $\begin{array}{l}\text { Xu et al., } \\
{[14]}\end{array}$ & $\begin{array}{l}\text { Flat } \\
\text { disk }\end{array}$ & $\begin{array}{l}\mathrm{D}=56 \mathrm{~mm} \\
\mathrm{t}=30 \mathrm{~mm}\end{array}$ & $\begin{array}{l}\mathrm{D}=30 \\
\mathrm{~mm}\end{array}$ & Copper & Copper & Water & $120 \mathrm{~W}$ & $90^{\circ} \mathrm{C}$ \\
\hline 2018 & $\begin{array}{l}\text { He et al., } \\
{[15]}\end{array}$ & Square & $\begin{array}{l}\mathrm{W}=80 \mathrm{~mm} \\
\mathrm{~L}=80 \mathrm{~m} \\
\mathrm{~T}=21 \mathrm{~mm}\end{array}$ & $\begin{array}{l}54.76 \\
\mathrm{~cm}^{2}\end{array}$ & Copper & Nickel & R245fa & $160 \mathrm{~W}$ & $55^{\circ} \mathrm{C}$ \\
\hline 2018 & $\begin{array}{l}\text { Anand et } \\
\text { al., [16] }\end{array}$ & Oval & $\mathrm{D}=79 \mathrm{~mm}$ & $\begin{array}{l}\mathrm{D}=45 \\
\mathrm{~mm}\end{array}$ & $\begin{array}{l}\text { Aluminu } \\
\text { m alloy }\end{array}$ & Nickel & $\begin{array}{l}\text { Acetone } \\
\text { Methano } \\
\text { I } \\
\text { Ethanol } \\
\mathrm{N} \text { - } \\
\text { pentane }\end{array}$ & $\begin{array}{l}160 \mathrm{~W} \\
180 \mathrm{~W} \\
140 \mathrm{~W} \\
120 \mathrm{~W}\end{array}$ & $\begin{array}{l}60^{\circ} \mathrm{C} \\
63^{\circ} \mathrm{C} \\
67^{\circ} \mathrm{C} \\
43^{\circ} \mathrm{C}\end{array}$ \\
\hline 2019 & $\begin{array}{l}\text { Zhang et } \\
\text { al., [17] }\end{array}$ & $\begin{array}{l}\text { Rectan } \\
\text { gular }\end{array}$ & $\begin{array}{l}\mathrm{W}=45 \mathrm{~mm} \\
\mathrm{~L}=47 \mathrm{~mm} \\
\mathrm{t}=5.3 \mathrm{~mm}\end{array}$ & $\begin{array}{l}2.5 \times \\
2.5 \\
\mathrm{~mm}^{2}\end{array}$ & Copper & $\begin{array}{l}\text { Carbon } \\
\text { fiber }\end{array}$ & Water & $25 \mathrm{~W}$ & $100^{\circ} \mathrm{C}$ \\
\hline
\end{tabular}




\section{Table 2}

Summary of studies on LHPs having a flat evaporator with aside compensation chamber (AS-CC)

\begin{tabular}{|c|c|c|c|c|c|c|c|c|c|}
\hline Year & Author & $\begin{array}{l}\text { Evaporator } \\
\text { shape }\end{array}$ & $\begin{array}{l}\text { Evaporator } \\
\text { dimensions }\end{array}$ & $\begin{array}{l}\text { Source } \\
\text { area }\end{array}$ & $\begin{array}{l}\text { Housing } \\
\text { material }\end{array}$ & $\begin{array}{l}\text { Wick } \\
\text { material }\end{array}$ & $\begin{array}{l}\text { Working } \\
\text { fluid }\end{array}$ & $\begin{array}{l}\text { Max. } \\
\text { heat } \\
\text { load }\end{array}$ & $\begin{array}{l}\text { Max. } \\
\text { evaporator } \\
\text { temp. }\end{array}$ \\
\hline 2007 & $\begin{array}{l}\text { Singh et al., } \\
{[18]}\end{array}$ & Rectangular & $\begin{array}{l}\mathrm{W}=35 \\
\mathrm{~mm} \\
\mathrm{~L}=45 \mathrm{~mm} \\
\mathrm{t}=5 \mathrm{~mm}\end{array}$ & $\begin{array}{l}22 \times 22 \\
\mathrm{~mm}^{2}\end{array}$ & Copper & Nickel & Water & $\begin{array}{l}50 \\
W\end{array}$ & $98^{\circ} \mathrm{C}$ \\
\hline 2008 & $\begin{array}{l}\text { Joung et al., } \\
\text { [19] }\end{array}$ & Rectangular & $\begin{array}{l}\mathrm{W}=50 \\
\mathrm{~mm} \\
\mathrm{~L}=54 \mathrm{~mm} \\
\mathrm{t}=1 \mathrm{~mm}\end{array}$ & $\begin{array}{l}50 \times 50 \\
\mathrm{~mm}^{2}\end{array}$ & $\begin{array}{l}\text { Stainless } \\
\text { Steel }\end{array}$ & $\begin{array}{l}\text { Stainless } \\
\text { Steel }\end{array}$ & $\begin{array}{l}\text { Methyl } \\
\text { alcohol }\end{array}$ & $\begin{array}{l}30 \\
W\end{array}$ & $90^{\circ} \mathrm{C}$ \\
\hline 2010 & $\begin{array}{l}\text { Joung et al., } \\
{[20]}\end{array}$ & Rectangular & $\begin{array}{l}\mathrm{W}= \\
52.4 \mathrm{~mm} \\
\mathrm{~L}=56 \mathrm{~mm} \\
\mathrm{t}=20 \mathrm{~mm}\end{array}$ & $\begin{array}{l}50 \times 50 \\
\mathrm{~mm}^{2}\end{array}$ & $\begin{array}{l}\text { Stainless } \\
\text { Steel }\end{array}$ & $\begin{array}{l}\text { Stainless } \\
\text { Steel }\end{array}$ & Acetone & $\begin{array}{l}260 \\
W\end{array}$ & $105^{\circ} \mathrm{C}$ \\
\hline 2011 & $\begin{array}{l}\text { Maydanik et } \\
\text { al., [21] }\end{array}$ & Flat oval & $\begin{array}{l}\mathrm{W}=42 \\
\mathrm{~mm} \\
\mathrm{~L}=80 \mathrm{~mm} \\
\mathrm{t}=7 \mathrm{~mm}\end{array}$ & $\begin{array}{l}30 \times 30 \\
\mathrm{~mm}^{2}\end{array}$ & Copper & Copper & Water & $\begin{array}{l}1174 \\
W\end{array}$ & $110^{\circ} \mathrm{C}$ \\
\hline 2011 & $\begin{array}{l}\text { Becker et } \\
\text { al., [22] }\end{array}$ & Flat oval & $\begin{array}{l}\mathrm{W}=42 \\
\mathrm{~mm} \\
\mathrm{~L}=85 \mathrm{~mm} \\
\mathrm{t}=7 \mathrm{~mm}\end{array}$ & $\begin{array}{l}\text { Not } \\
\text { indicated }\end{array}$ & Copper & Copper & Water & $\begin{array}{l}100 \\
W\end{array}$ & $85^{\circ} \mathrm{C}$ \\
\hline 2012 & $\begin{array}{l}\text { Zhang et al., } \\
\text { [23] }\end{array}$ & Rectangular & $\begin{array}{l}W= \\
36.5 \mathrm{~mm} \\
\mathrm{~L}=100 \\
\mathrm{~mm} \\
\mathrm{t}=8 \mathrm{~mm}\end{array}$ & $\begin{array}{l}20 \times 40 \\
\mathrm{~mm}^{2}\end{array}$ & Copper & Copper & Water & $\begin{array}{l}110 \\
W\end{array}$ & $82^{\circ} \mathrm{C}$ \\
\hline 2012 & $\begin{array}{l}\text { Wang et al., } \\
{[24]}\end{array}$ & Rectangular & $\begin{array}{l}W= \\
36.5 \mathrm{~mm} \\
L=100 \\
\mathrm{~mm} \\
\mathrm{t}=8 \mathrm{~mm}\end{array}$ & $\begin{array}{l}20 \times 40 \\
\mathrm{~mm}^{2}\end{array}$ & Copper & Copper & Water & $\begin{array}{l}120 \\
W\end{array}$ & $110^{\circ} \mathrm{C}$ \\
\hline 2013 & $\begin{array}{l}\text { Choi et al., } \\
\text { [25] }\end{array}$ & Flat disk & $\begin{array}{l}\text { Not } \\
\text { indicated }\end{array}$ & $\begin{array}{l}\mathrm{D}=30 \\
\mathrm{~mm}\end{array}$ & Copper & $\begin{array}{l}\text { Copper - } \\
\text { Nickel }\end{array}$ & Water & $\begin{array}{l}250 \\
W\end{array}$ & $50^{\circ} \mathrm{C}$ \\
\hline 2015 & $\begin{array}{l}\text { Chernysheva } \\
\text { et al., [26] }\end{array}$ & Flat oval & $\begin{array}{l}\mathrm{W}=42 \\
\mathrm{~mm} \\
\mathrm{~L}=80 \mathrm{~mm} \\
\mathrm{t}=7 \mathrm{~mm}\end{array}$ & $\begin{array}{l}30 \times 30 \\
\mathrm{~mm}^{2}\end{array}$ & Copper & Copper & Water & $\begin{array}{l}600 \\
W\end{array}$ & $100^{\circ} \mathrm{C}$ \\
\hline 2015 & $\begin{array}{l}\text { Maydanik et } \\
\text { al., [27] }\end{array}$ & Rectangular & $\begin{array}{l}\mathrm{W}=42 \\
\mathrm{~mm} \\
\mathrm{~L}=80 \mathrm{~mm} \\
\mathrm{t}=7 \mathrm{~mm}\end{array}$ & $\begin{array}{l}42 \times 42 \\
\mathrm{~mm}^{2}\end{array}$ & Copper & Copper & Acetone & $\begin{array}{l}50 \\
W\end{array}$ & $70^{\circ} \mathrm{C}$ \\
\hline 2019 & $\begin{array}{l}\text { Odagiri and } \\
\text { Nagano [28] }\end{array}$ & Rectangular & $\begin{array}{l}\mathrm{W}=68 \\
\mathrm{~mm} \\
\mathrm{~L}=51 \mathrm{~mm} \\
\mathrm{t}=15 \mathrm{~mm}\end{array}$ & $\begin{array}{l}30 \times 47.5 \\
\mathrm{~mm}^{2}\end{array}$ & $\begin{array}{l}\text { Stainless } \\
\text { Steel }\end{array}$ & $\begin{array}{l}\text { Stainless } \\
\text { Steel }\end{array}$ & Acetone & $\begin{array}{l}280 \\
W\end{array}$ & $100^{\circ} \mathrm{C}$ \\
\hline
\end{tabular}

In addition to the geometrical shape of the evaporator and the position of the compensation chamber, other technological aspects, namely the material of the evaporator case and the porous structure, can play an important role in the design of the LHPs. The evaporator material may be copper, which is the most used material in the literature, aluminum, or stainless steel. The material of the capillary structure also influences the thermal performance of the LHPs. Consequently, the 
porous structure is made of copper, nickel, or stainless steel. The working fluids must be compatible with the materials of the LHP. The most widely used working fluid is water that is compatible with most of the materials mentioned above except for aluminum for which ammonia is used. The other fluids used are acetone, methanol, ethanol, and methyl alcohol.

Comparing the available steady-state models for LHPs with a flat evaporator, it became necessary to carry out a more refined investigation towards the development of an analytical model that could better describe LHP performance. Focusing on this matter, the proposed model of a copper-water LHP with a flat evaporator uses a different methodology than those published previously. In this steady-state model, the thermal evaporator resistance equation is solved using a correlation established from a dimensionless analysis and is expressed as a function of heat input. Nonetheless, the evaporator resistance in the existing models is fixed independently of the heat load applied. The heat leak transferred through the porous wick and the evaporator wall and the heat dissipated by evaporation at the wick-groove interface are taken into account in this model. The model was validated by comparing the experimental results found in the literature and the predicted ones. Finally, a parametric study was carried out to simulate the effects of various parameters on the LHP thermal performance.

\section{Literature Survey on LHP Models and Critical Review}

The thermal behavior of the LHPs is very sensitive to the operating conditions. The steady-state modeling of such systems has been the object of many researches works that have aimed to predict their operation and optimize their design. Table 3 summarizes the main studies dealing with LHP's steady-state operation. The LHP models can be divided according to the evaporator shape and the compensation chamber location. Most of which are 1D models and are based on the steady-state energy balance equations at each component of the system and the thermodynamic relationships. The main studied parameters can be classified into three groups. The first one consists of the geometrical characteristics of the LHP components, namely the depth, the width and the number of the grooves, the thickness of the wick, the length and the radius of the vapor and liquid lines, as well as the length of the condenser. The second group of parameters concerns the operating conditions, such as the heat input power, the sink and ambient temperatures, the heat exchange with the ambient, the LHP elevation, the presence of non-condensable gas, and the fill charge. The third group of parameters comprises the thermo-hydraulic properties of the capillary structure, such as the effective thermal conductivity, porosity, permeability, and the material.

Although previous studies on LHP modeling contributed significantly to the understanding of the physical phenomena involved in the operation of such systems, the literature survey evidences a lack in the modeling of the evaporation phenomenon within the capillary wick (Table 4). Indeed, many of the published models did not present details about how the evaporation thermal conductance is determined or modeled [29-47,49]. Besides, according to the literature review, to date, no models have been established for the prediction of the evaporation heat transfer coefficient in the capillary structures. Moreover, the evaporation heat transfer coefficient depends on several parameters, such as the thermal contact between the evaporator wall and the capillary wick, the wettability of the liquid, the working fluid, the heat input power, the nature of the capillary wick, and its hydrodynamic characteristics, such as porosity and permeability, and the temperature of the compensation chamber, which depends significantly on the operating conditions of the heat sink in the condenser. As such characteristics are not detailed in the published experimental studies, the evaporation thermal resistance was adjusted in the models to obtain a good agreement between the experimental results and those of the models [32,35]. 
Besides, some published works also considered fixed values of the evaporation thermal resistance (or thermal conductance). They are either based on the experimental results or fixed arbitrarily by considering an order of magnitude of the evaporation heat transfer coefficient $[29,33,45]$. Moreover, in some works, the evaporation heat transfer coefficient is determined by expressions which are not necessarily valid for the evaporation phenomenon in porous media $[30,38,41,42,44]$.

This work aimed to contribute to the modeling of the evaporation within the capillary wick. Hence, an analytical model was proposed for which the evaporation heat transfer coefficient was determined from a correlation based on a dimensionless analysis. The coefficients of this correlation were determined from the experimental results.

Table 3

Main steady-state models on LHP

\begin{tabular}{|c|c|c|c|c|}
\hline Author (year) & Model & $\begin{array}{l}\text { Evaporator } \\
\text { shape }\end{array}$ & $\begin{array}{l}\text { Compensation } \\
\text { chamber } \\
\text { location }\end{array}$ & Studied parameters \\
\hline Chuang [29] (2003) & $1 \mathrm{D}$ & Cylindrical & AS-CC & Heat input power \\
\hline Furukawa [30] (2006) & $1 \mathrm{D}$ & Cylindrical & AS-CC & $\begin{array}{l}\text { Heat input power, capillary pore radius, } \\
\text { wick porosity, wick dimensions, } \\
\text { vapor/liquid line length, evaporator } \\
\text { length, and condenser dimensions }\end{array}$ \\
\hline Adoni et al., [31] (2007) & $1 \mathrm{D}$ & Cylindrical & AS-CC & Heat input power and fill charge \\
\hline Launay et al., [32] (2008) & $1 \mathrm{D}$ & Cylindrical & OS-CC & $\begin{array}{l}\text { Working fluid, elevation, wick thermal } \\
\text { conductivity, the temperature } \\
\text { difference between the ambient and } \\
\text { the heat sink }\end{array}$ \\
\hline Bai et al., [33] (2009) & $1 \mathrm{D}$ & Cylindrical & AS-CC & $\begin{array}{l}\text { Sink temperature, ambient } \\
\text { temperature, elevation, nature of the } \\
\text { wick, and working fluid inventory }\end{array}$ \\
\hline Singh et al., [34] (2009) & $1 \mathrm{D}$ & Flat disk & OS-CC & Heat input power \\
\hline $\begin{array}{l}\text { Hamdan and Elnajjar [37] } \\
\text { (2009) }\end{array}$ & $1 \mathrm{D}$ & Flat & AS-CC & $\begin{array}{l}\text { Pipe length, pipe diameter, condenser } \\
\text { temperature, and heat load }\end{array}$ \\
\hline Lin et al., [39] (2011) & $1 \mathrm{D}$ & Cylindrical & AS-CC & $\begin{array}{l}\text { Pore size distribution (biporous and } \\
\text { monoporous wick) and presence of } \\
\text { vapor blanket. }\end{array}$ \\
\hline $\begin{array}{l}\text { Chernysheva and } \\
\text { Maydanik [35] (2012) }\end{array}$ & $3 D$ & Flat & AS-CC & $\begin{array}{l}\text { Heat input power at constant ambient- } \\
\text { sink temperature }\end{array}$ \\
\hline $\begin{array}{l}\text { Chernysheva et al., [36] } \\
\text { (2013) }\end{array}$ & $3 D$ & Flat & AS-CC & Heat input power and elevation \\
\hline Siedel et al., [40] (2013) & $2 \mathrm{D}$ & Flat disk & OS-CC & $\begin{array}{l}\text { Evaporator heat transfer coefficient, } \\
\text { the thermal conductivity of the liquid } \\
\text { and vapor lines, wick thermal } \\
\text { conductivity and its thickness, } \\
\text { evaporator sidewall material and its } \\
\text { thickness and insulation }\end{array}$ \\
\hline $\begin{array}{l}\text { Ghajar and Darabi [38] } \\
\text { (2014) }\end{array}$ & $1 \mathrm{D}$ & Cylindrical & OS-CC & Groove dimensions and working fluid \\
\hline Bai et al., [41] (2014) & $1 \mathrm{D}$ & Cylindrical & AS-CC & Heat input power and elevation \\
\hline Bai et al., [42] (2015) & $1 \mathrm{D}$ & Cylindrical & AS-CC & Elevation \\
\hline Siedel et al., [44] (2015) & $2 \mathrm{D}$ & Flat disk & OS-CC & $\begin{array}{l}\text { Presence of noncondensable gas and } \\
\text { the thermal conductivity of the wick }\end{array}$ \\
\hline $\begin{array}{l}\text { Chernyshevaand Maydanik } \\
\text { [45] (2016) }\end{array}$ & 1D & Flat disk & OS-CC & $\begin{array}{l}\text { Convective component of the heat } \\
\text { transfer on the evaporator thermal } \\
\text { state and heat exchange processes in } \\
\text { the evaporation zone. }\end{array}$ \\
\hline
\end{tabular}




\begin{tabular}{|c|c|c|c|c|}
\hline Zhu and Yu [43] (2016) & $1 \mathrm{D}$ & Flat & OS-CC & $\begin{array}{l}\text { The thickness of the wick, length of the } \\
\text { condenser, the inner diameter of the } \\
\text { vapor line, and the mass flow rate }\end{array}$ \\
\hline Esarte et al., [46] (2016) & $1 \mathrm{D}$ & Cylindrical & AS-CC & $\begin{array}{l}\text { Effect of the length and radius of the } \\
\text { vapor lines, the wick thickness, and the } \\
\text { condensing temperature }\end{array}$ \\
\hline Weng and Leu [47] (2016) & $1 \mathrm{D}$ & Cylindrical & AS-CC & Effect of the heat input power \\
\hline Pozhilov et al., [48] (2017) & $3 D$ & Cylindrical & AS-CC & $\begin{array}{l}\text { The processes of evaporation in the } \\
\text { vapor grooves }\end{array}$ \\
\hline $\begin{array}{l}\text { Ramasamy et al., [49] } \\
\text { (2018) }\end{array}$ & $1 \mathrm{D}$ & Cylindrical & AS-CC & $\begin{array}{l}\text { Initial flow distribution, heat load, } \\
\text { orientation, and sink temperature }\end{array}$ \\
\hline Li et al., [50] (2019) & $1 \mathrm{D}$ & Flat & OS-CC & $\begin{array}{l}\text { Heat flux, surface wettability on the } \\
\text { patterns, dynamics of the liquid-vapor } \\
\text { interface, liquid volume fraction, } \\
\text { temperature distribution at wick-fin, } \\
\text { wick groove interfaces, and effective } \\
\text { heat transfer coefficient of the } \\
\text { evaporator. }\end{array}$ \\
\hline $\begin{array}{l}\text { Chernysheva and } \\
\text { Maydanik [51] (2019) }\end{array}$ & $1 \mathrm{D}$ & Cylindrical & AS-CC & $\begin{array}{l}\text { Temperature and pressure distribution } \\
\text { in the evaporator and pressure drop in } \\
\text { the wick. }\end{array}$ \\
\hline
\end{tabular}

Table 4

Determination of the evaporation thermal resistance in the LHP models

\begin{tabular}{|c|c|}
\hline Author (year) & Evaporation thermal resistance \\
\hline Chuang et al., [29] (2003) & $\begin{array}{l}\text { The evaporation heat transfer coefficient is calculated from experimental } \\
\text { data }\end{array}$ \\
\hline Furukawa [30] (2006) & $\begin{array}{l}\text { The evaporation thermal conductance is given by Eq. (11) (Chernysheva and } \\
\text { Maydanik [35]) }\end{array}$ \\
\hline Adoni et al., [31] (2007) & Not detailed \\
\hline Launay et al., [32] (2008) & $\begin{array}{l}\text { It is adjusted to obtain good agreement between experimental and model } \\
\text { results }\end{array}$ \\
\hline Bai et al., [33] (2009) & Fixed at a constant value \\
\hline Singh et al., [34] (2009) & Not detailed \\
\hline Hamdan and Elnajjar [37] (2009) & Not detailed \\
\hline Lin et al., [39] (2011) & $\begin{array}{l}\text { The evaporative heat transfer coefficient is calculated by Eq. (19) } \\
\text { (Chernysheva and Maydanik [45]) }\end{array}$ \\
\hline $\begin{array}{l}\text { Chernysheva and Maydanik [35] } \\
\text { (2012) }\end{array}$ & $\begin{array}{l}\text { The evaporation heat transfer coefficient is fixed initially and then modified } \\
\text { by an iterative method according to Eq. (38) (Siedel et al., [40]) }\end{array}$ \\
\hline Chernysheva et al., [36] (2013) & $\begin{array}{l}\text { The heat transfer in the compensation chamber is analyzed. The heat } \\
\text { transfer coefficient is determined from Eq. (8) (Bai et al., [41]) }\end{array}$ \\
\hline Siedel et al., [40] (2013) & $\begin{array}{l}\text { The evaporation heat transfer coefficient is calculated according to Eq. (45) } \\
\text { (Weng and Leu [47]) }\end{array}$ \\
\hline Ghajar and Darabi [38] (2014) & $\begin{array}{l}\text { The evaporative heat transfer coefficient is calculated by a micro-region } \\
\text { model }\end{array}$ \\
\hline Bai et al., [41] (2014) & $\begin{array}{l}\text { The evaporation heat transfer coefficient is calculated by the Fourier law of } \\
\text { thermal conduction of liquid-saturated wick (Eq. (6) (Pozhilov et al., [48]) }\end{array}$ \\
\hline Bai et al., [42] (2015) & Not detailed \\
\hline Siedel et al., [44] (2015) & $\begin{array}{l}\text { The evaporative heat transfer coefficient is calculated by Eq. (29) and Eq. } \\
\text { (30) (Li et al., [51]) }\end{array}$ \\
\hline Zhu and Yu [43] (2016) & Not detailed \\
\hline Chernysheva et al., [45] (2016) & The evaporation heat transfer coefficient is fixed at a constant value \\
\hline Esarte et al., [46] (2016) & Not detailed \\
\hline Weng and Leu [47] (2016) & Not detailed \\
\hline Ramasamy et al., [49] (2018) & $\begin{array}{l}\text { It varies with the heat load according to the values obtained from } \\
\text { experiments }\end{array}$ \\
\hline
\end{tabular}




\section{Description of the Modeled LHP}

The model developed in this study was validated based on the experimental results of Chernysheva et al., [26] as it is the only published experimental study that gives complete information and details about the geometrical characteristics of the LHP and the experimental operating conditions. Moreover, the experimental curves of the evaporator, as well as the vapor temperatures, are presented as a function of the heat load for different operating conditions, such as the heat sink temperature, the mass flow rate of the cooling water, and the tilt angle. Accordingly, it is important to recall the main LHP geometrical characteristics and the wicking structure since they are important for model development.

Chernysheva et al., [26] tested a copper-water LHP with a flat oval evaporator (Figure 1(a)) measuring $80 \times 42 \times 7 \mathrm{~mm}$. The details of the capillary structure and the grooves are shown in Figure 1 (b) to Figure $1(d)$. The power input delivered to the evaporator is concentrated in an active zone measuring $32 \times 42 \mathrm{~mm}^{2}$, and the evaporator includes vapor-removal grooves, as depicted in Figure 1(b). The vapor line and the water-cooled condenser tubes have an inner diameter of $4 \mathrm{~mm}$ and are respectively 305 and $160 \mathrm{~mm}$ long. The liquid line tube has a length of $810 \mathrm{~mm}$ and an inner diameter equal to $3 \mathrm{~mm}$. The wick is made of sintered copper powder with a pore radius of $27 \mu \mathrm{m}$ and a porosity equal to $46 \%$. To ensure the cooling of the condenser, a cooling plastic jacket was used through which water is pumped [26]. The main characteristics of the LHP are indicated in Table 5.

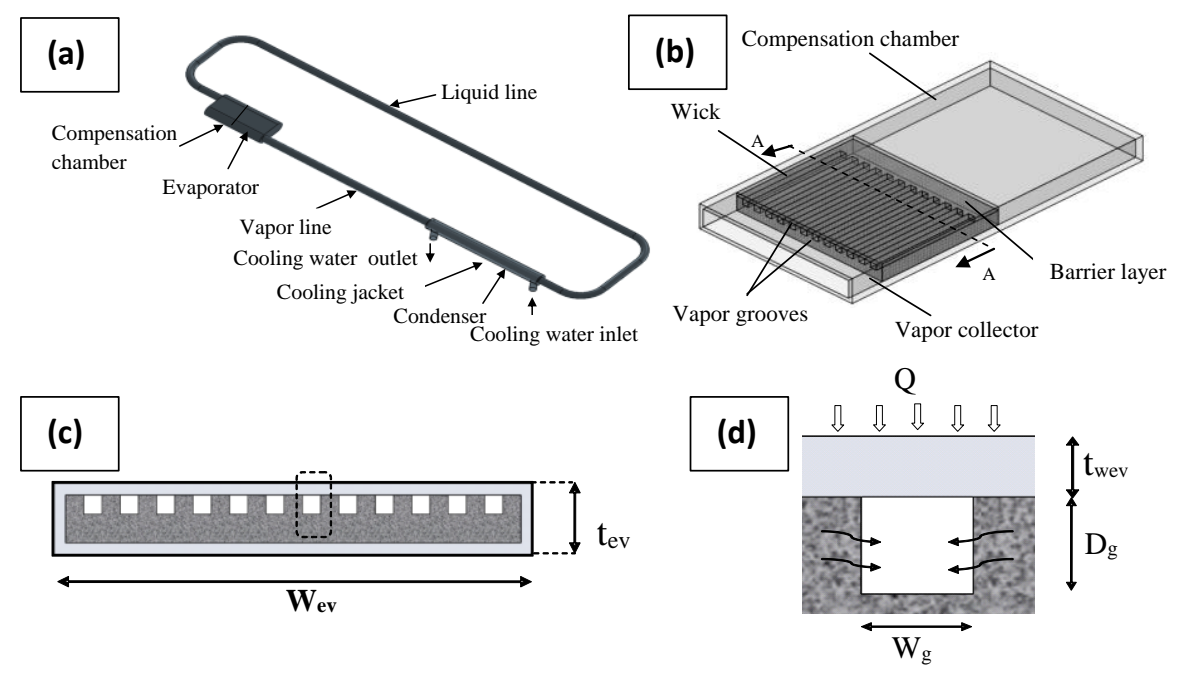

Fig. 1. General view of the copper-water loop heat pipe studied [52]: (a) General view, (b) Evaporator details, (c) Groove details, and (d) Geometrical parameters of the grooves 


\section{Table 5}

Main characteristics of the modeled copper-water LHP

\begin{tabular}{|c|c|}
\hline Evaporator & \\
\hline Total length, $\mathrm{L}$ & $80 \mathrm{~mm}$ \\
\hline Width, $\mathrm{W}_{\mathrm{ev}}$ & $42 \mathrm{~mm}$ \\
\hline Thickness, tev & $7 \mathrm{~mm}$ \\
\hline Case thickness, $t_{\text {wev }}$ & $0.5 \mathrm{~mm}$ \\
\hline Active zone length, $L_{a}$ & $32 \mathrm{~mm}$ \\
\hline Compensation chambe & \\
\hline Length, $L_{c c}$ & $40 \mathrm{~mm}$ \\
\hline Vapor-removal groove & \\
\hline Number, $\mathrm{Ng}_{\mathrm{g}}$ & 12 \\
\hline Length, $\mathrm{Lg}$ & $33 \mathrm{~mm}$ \\
\hline Width, $W_{g}$ & $1.8 \mathrm{~mm}$ \\
\hline Depth, $D_{g}$ & $1.8 \mathrm{~mm}$ \\
\hline Wick & \\
\hline Wick length, $L_{w}$ & $33 \mathrm{~mm}$ \\
\hline Porosity, $\varphi_{w}$ & 0.46 \\
\hline Pore radius, $R_{p}$ & $27 \mu \mathrm{m}$ \\
\hline Heating area & \\
\hline Length, $\mathrm{L}_{a}$ & $30 \mathrm{~mm}$ \\
\hline Width, Wa & $30 \mathrm{~mm}$ \\
\hline Thickness, $t_{a}$ & $1 \mathrm{~mm}$ \\
\hline Vapor line & \\
\hline Length, $L_{v}$ & $305 \mathrm{~mm}$ \\
\hline Inner diameter, $\mathrm{D}_{\mathrm{vi}}$ & $4 \mathrm{~mm}$ \\
\hline Outer diameter, $\mathrm{D}_{\mathrm{vo}}$ & $5 \mathrm{~mm}$ \\
\hline Liquid line & \\
\hline Length, $\mathrm{L}_{\mathrm{I}}$ & $810 \mathrm{~mm}$ \\
\hline Inner diameter, $\mathrm{D}_{\mathrm{li}}$ & $3 \mathrm{~mm}$ \\
\hline Outer diameter, $\mathrm{D}_{\text {lo }}$ & $4 \mathrm{~mm}$ \\
\hline Condenser & \\
\hline Length, $L_{c}$ & $160 \mathrm{~mm}$ \\
\hline Inner diameter, $\mathrm{D}_{\mathrm{ci}}$ & $4 \mathrm{~mm}$ \\
\hline Outer diameter, $\mathrm{D}_{\text {co }}$ & $5 \mathrm{~mm}$ \\
\hline Cooling jacket & \\
\hline Inner diameter, $D_{\text {isink }}$ & $8 \mathrm{~mm}$ \\
\hline Outer diameter, $D_{\text {osink }}$ & $11 \mathrm{~mm}$ \\
\hline Rate of cooling water & $4 \pm 0.5 \mathrm{l} / \mathrm{min}$ \\
\hline
\end{tabular}

\section{Model Description}

In this section, to predict the LHP performance and optimize the geometrical parameters of the evaporator and the wick, a steady-state model will be briefly described. This analytical model is based on that developed by Gabsi et al., [52]. The LHP geometry used in the model is presented in Figure 1. It includes a flat evaporator related to a compensation chamber according to AS-CC technology and connected to the heat source, a condenser to dissipate the heat load, and vapor and liquid lines to transport the working fluid between the two components. When a heat load is applied at the evaporator, the temperature rises, and the liquid vaporizes. The working fluid flows through the vapor line and reaches the condenser due to the temperature difference between the evaporator and the condenser. Then, the condensate flows toward the evaporator using the capillary wick located in the compensation chamber and the evaporator. The capillary pressure created in the core of the evaporator is responsible for the fluid circulation in the LHP. The model is based on the 
equations of momentum and energy balances applied to each component of the LHP. Two thermodynamic relations enable the closing of the equation system.

\subsection{Momentum Balance Equations}

To ensure the circulation of the working fluid in the LHP, the capillary driving pressure generated in the capillary structure must exceed the pressure drops according to the following relationship

$\Delta P_{\text {cap }, \text { max }}=\frac{2 \sigma \cos (\beta)}{R_{p}} \geq \Delta P_{g}+\Delta P_{v l}+\Delta P_{l l}+\Delta P_{w}+\Delta P_{v g}$

$\Delta \mathrm{P}_{\mathrm{Il}}, \Delta \mathrm{P}_{\mathrm{vl}}, \Delta \mathrm{P}_{\mathrm{w}}$, and $\Delta \mathrm{P}_{\mathrm{vg}}$ are the pressure drops in the liquid line, the vapor line, the porous wick, and the vapor grooves, respectively. $\Delta \mathrm{P}_{\mathrm{g}}$ is the hydrostatic pressure drop. $\Delta \mathrm{P}_{\text {cap,max }}$ is the maximum driving capillary pressure. The vapor and liquid pressure drops are expressed as

$\Delta P_{v l}=F_{v} L_{v} Q_{i n}$

$\Delta P_{l l}=F_{l} L_{l} Q_{\text {in }}$

$Q_{\text {in }}$ is the heat input power. $F_{v}$ and $F_{l}$ are the friction factors in the vapor and liquid lines, respectively. They are given by

$$
\begin{aligned}
& F_{v}=8 \mu_{v} /\left(\rho_{v} r_{v}^{2} A_{v} \Delta h_{v}\right) \\
& F_{l}=8 \mu_{l} /\left(\rho_{l} r_{l}^{2} A_{l} \Delta h_{v}\right)
\end{aligned}
$$

$A_{I}$ and $A_{v}$ are respectively the cross-sections of the liquid and the vapor lines. $r_{I}$ and $r_{v}$ are the radius of the liquid and the vapor lines, respectively. The vapor pressure drops in the grooves, $\Delta \mathrm{P}_{\mathrm{vg}}$, can be written as

$\Delta P_{v g}=F_{v g} L_{g} Q_{i n}$

$\mathrm{Lg}_{\mathrm{g}}$ is the groove length and $\mathrm{F}_{\mathrm{vg}}$ is the friction factor in the grooves that are expressed by

$F_{v g}=\mu_{v} /\left(K_{g} N_{g} A_{g} \Delta h_{v} \rho_{v}\right)$

$\mathrm{A}_{\mathrm{g}}, \mathrm{N}_{\mathrm{g}}$, and $\mathrm{Kg}$ are the cross-section, the number, and the permeability of the grooves, respectively. The permeability of the grooves, $\mathrm{K}_{\mathrm{g}}$, is expressed as [6]

$K_{g}=\left(D_{h g}^{2} \varphi_{g}\right) /\left(2 P_{0}\right)$

$D_{h g}$ and $\varphi_{g}$ are the hydraulic diameter and the porosity of the grooves, respectively. They are given by:

$D_{h g}=\left(4 D_{g} W_{g}\right) /\left(2 D_{g}+W_{g}\right)$

$\varphi_{g}=S_{g} /\left(S_{g}+W_{g}\right)$ 
The Poiseuille number, $\mathrm{P}_{\mathrm{o}}$, is calculated according to Gabsi et al., [52]

$P_{0}=24\left(1-1.355 \alpha+1.947 \alpha^{2}-1.701 \alpha^{3}+0.956 \alpha^{4}-0.254 \alpha^{5}\right)$

where

$\alpha=\min \left(W_{g} / D_{g}, D_{g} / W_{g}\right)$

The liquid pressure drops in the wick, $\Delta \mathrm{P}_{\mathrm{w}}$, is expressed as

$\Delta P_{w}=F_{w} L_{w} \mathrm{Q}_{\text {in }}$

$L_{w}$ is the wick length and $F_{w}$ is the friction factor in the wick written as follows

$F_{w}=\mu_{l} /\left(K_{w} A_{w} \Delta h_{v} \rho_{l}\right)$

$A_{w}$ is the porous cross-section. $K_{w}$ is the wick permeability which is calculated by a general correlation including the pore diameter, $D_{p}$, and the porosity of the porous medium, $\varphi_{w}$ [52]

$K_{w}=D_{p}{ }^{2} \varphi_{w}{ }^{3} /\left(150 \times\left(1-\varphi_{w}\right)^{2}\right)$

The component of the gravitational force acts along the longitudinal axis. Consequently, an axial hydrostatic pressure drop is generated and is expressed as

$\Delta P_{g}=\rho_{v} g \Delta H$

The hydrostatic pressure drop depends on the elevation, $\Delta \mathrm{H}$, between the evaporator and the condenser. A positive elevation $(\Delta \mathrm{H}>0)$ corresponds to the case where the condenser is placed above the evaporator, while a negative elevation $(\Delta \mathrm{H}<0)$ corresponds to the inverse.

\subsection{Thermodynamics Equations}

Three different thermodynamic equilibrium states exist for each LHP component. Between these three states in the evaporator, the compensation chamber, and the condenser, the temperature variations are related to the pressure differences by the following relationships [52]

$$
\begin{aligned}
& T_{v}-T_{c}=(\partial T / \partial P)\left(\Delta P_{v l}+\Delta P_{v g}+\rho_{v} g \Delta H\right) \\
& T_{c}-T_{c c}=(\partial T / \partial P)\left(\Delta P_{l l}-\rho_{l} g \Delta H\right)
\end{aligned}
$$

The slope of the saturation curve $\partial \mathrm{T} / \partial \mathrm{P}$ is expressed in terms of thermo-physical properties of the fluid by the Clausius-Clapeyron relationship

$\frac{\partial T}{\partial P}=\frac{T\left(1 / \rho_{v}-1 / \rho_{l}\right)}{\Delta h_{v}}$ 


\subsection{Energy Balance Equations}

\subsubsection{Energy balance equations for the evaporator section}

The heat input power, $Q_{\text {in, }}$ is transferred according to three paths. The first one is transferred to the compensation chamber, $Q_{a x i a l}$, the second one is lost to the ambient, $Q_{a m b}$, and the third one serves to the liquid evaporation within the wick, $Q_{\text {ev }}$ (Figure 2). Hence, the energy balance at the evaporator can be written as

$Q_{i n}=Q_{a x i a l}+Q_{a m b}+Q_{e v}=G_{a x w}\left(T_{e v}-T_{c c}\right)+G_{a m b e v}\left(T_{e v}-T_{a m b}\right)+G_{e v}\left(T_{e v}-T_{v}\right)$

$T_{e v}, T_{c c}, T_{a m b}$, and $T_{v}$ are the evaporator, the compensation chamber, the ambient, and the vapor temperatures, respectively. $G_{a x w}$ represents the thermal conductance between the evaporator wall and the compensation chamber wall, and it can be calculated by considering expressions for heat spreading resistance as it is detailed in the study by Gabsi et al., [52]. Gambev represents the thermal conductance between the ambient air and the external surface of the evaporator, and it can be expressed by the classical formula for convective heat transfer mode. $\mathrm{G}_{\mathrm{ev}}$ is the thermal conductance between the evaporator wall and the liquid-vapor interface within the porous wick, and it associates two thermal conductances in parallel according to

$\frac{1}{G_{e v}}=\frac{1}{G_{w e v}}+\frac{1}{G_{s p}}$

where $\mathrm{G}_{\text {wev }}$ is the thermal conductance that corresponds to the heat transfer by conduction through the evaporator wall, and $\mathrm{G}_{\mathrm{sp}}$ is the thermal conductance due to the phase change heat transfer within the porous wick. Detailed analysis of its determination is presented in section 5 .

By considering an energy balance equation, the third term in Eq. (20) can be written as

$$
G_{e v}\left(T_{e v}-T_{v}\right)=\dot{m} \Delta h_{v}+\dot{m} c_{p l}\left(T_{v}-T_{c c}\right)+G_{c v}\left(T_{v}-T_{c c}\right)
$$

$\dot{m}$ is the mass flow rate. $\Delta \mathrm{h}_{\mathrm{v}}$ and $\mathrm{c}_{\mathrm{pl}}$ are the latent heat and the liquid specific heat, respectively. $\mathrm{G}_{\mathrm{cv}}$ represents the conductive-convection thermal conductance.

The first term on the right of Eq. (22) is the latent heat which serves to the liquid evaporation, The second term is the sensible heat that serves to the heating of the liquid coming into the evaporator from the compensation chamber, and the third term is the heat transferred to the compensation chamber through the wick by conductive-convective heat transfer mode of which the thermal conductance is calculated according to Gabsi et al., [52]

$G_{c v}=\frac{\dot{m} c_{p l}}{\left(\exp \left(\eta t_{w}-1\right)\right.}$

$\dot{\mathrm{m}}$ is the mass flow rate and $t_{w}$ is the wick thickness.

$\eta$ is given by

$\eta=\frac{\dot{m} c_{p l}}{\left(\lambda_{p e f f} A_{e v}\right)}$ 
where $A_{\mathrm{ev}}$ is the evaporator heat transfer surface, and $I_{\text {peff }}$ is the effective thermal conductivity which is expressed by

$$
\lambda_{\text {peff }}=\lambda_{p}\left(\frac{2+\left(\lambda_{l} / \lambda_{p}\right)-2 \varphi_{w}\left(1-\lambda_{l} / \lambda_{p}\right)}{2+\left(\lambda_{l} / \lambda_{p}\right)+\varphi_{w}\left(1-\lambda_{l} / \lambda_{p}\right)}\right)
$$

$\lambda_{l}$ and $\lambda_{p}$ are the thermal conductivities of the liquid and the porous wick, respectively.

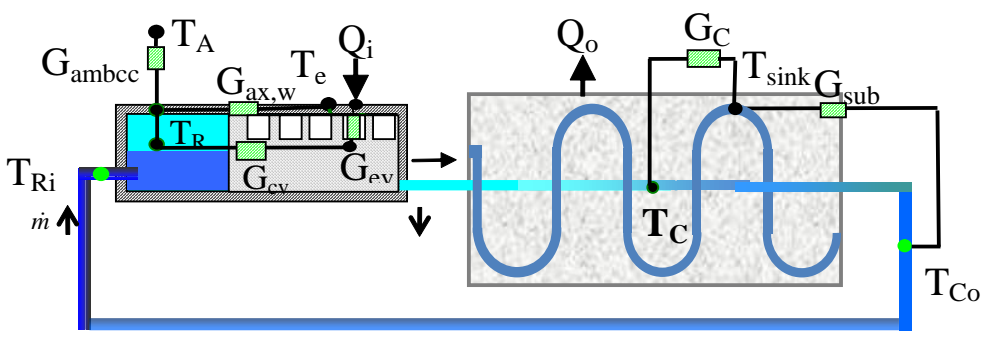

Fig. 2. LHP thermal conductance network

\subsubsection{Energy balance equations for the compensation chamber}

At the compensation chamber, a part of the heat flux rate, transported axially by conduction within the evaporator wall and transversally within the porous medium, is transferred by convection to the ambient, and the other part heats the liquid at the entrance of the reservoir, thus we can write

$\dot{m} c_{p l}\left(T_{c c}-T_{c c i}\right)+G_{a m b c c}\left(T_{c c}-T_{a m b}\right)=G_{a x w}\left(T_{e v}-T_{c c}\right)+G_{c v}\left(T_{v}-T_{c c}\right)$

$\mathrm{G}_{\text {ambcc }}$ is the thermal conductance between the compensation chamber and the ambient.

\subsubsection{Energy balance equations for the condenser}

The condenser can be subdivided into two zones: a condensation zone and a sub-cooled zone where the condensate is cooled under the condensation temperature. The energy balance overall the condenser can be written as

$\dot{Q}_{c}=\dot{m} \Delta h_{v}+\dot{m} c_{p l}\left(T_{c}-T_{c o}\right)$

$T_{c}$ is the condensation temperature and $T_{c o}$ is the condensate temperature at the condenser outlet. For the condensation zone, the energy balance can be written as

$\dot{m} \Delta h_{v}=G_{c}\left(T_{c}-T_{\text {sink }}\right)$

$\mathrm{G}_{\mathrm{c}}$ is the overall thermal conductance between the condensate in the condensation zone and the heat sink, and $T_{\text {sink }}$ is the heat sink temperature. It is expressed as the function of the condensation heat transfer coefficient, $h_{c}$, and the heat transfer coefficient between the outer condenser wall and the heat sink, $h_{\text {sink }}$ according to

$G_{C}=\frac{1}{\frac{1}{h_{c} A_{c i}}+\frac{1}{h_{\text {sink }} A_{c o}}+\frac{1}{2 \pi L_{\text {cond }} \lambda_{c}} \ln \frac{D_{c o}}{D_{c i}}}$ 
$G_{c}$ is the thermal conductivity of the condenser wall. $\mathrm{A}_{c i}$ and $\mathrm{A}_{c o}$ are the inner and outer heat transfer areas in the condensation zone, respectively. $D_{c o}$ and $D_{c i}$ are the inner and outer diameters of the condenser, respectively. $L_{\text {cond }}$ is the length of the condensation zone. The heat transfer coefficient, $h_{c}$, is calculated based on correlations that depend on the nature of the flow in the condensation zone. To determine the heat sink heat transfer coefficient, $\mathrm{h}_{\text {sink, }}$ standard Dittus-Boelter correlation is used.

For the sub-cooled zone, the energy balance is expressed as

$\dot{m} c_{p l}\left(T_{c}-T_{c o}\right)=\mathrm{G}_{\mathrm{sub}} \frac{\left(T_{c}-T_{c o}\right)}{\ln \left(\frac{T_{c o}-T_{\sin k}}{T_{c}-T_{\sin k}}\right)}$

$\mathrm{G}_{\text {sub }}$ is the thermal conductance between the condensate and the heat sink in the sub-cooled zone. It depends on the heat transfer coefficient between the outer condenser wall and the water cooling, $h_{\text {sink, }}$ and the heat transfer coefficient between the sub-cooled condensate and the inner condenser wall, $h_{\mathrm{lc}}$. Hence, $\mathrm{G}_{\text {sub }}$ is expressed as

$G_{\text {sub }}=\frac{\pi \mathrm{D}_{\mathrm{ci}}\left(L_{c}-L_{c o n d}\right)}{\frac{1}{h_{l c}}+\frac{1}{h_{\sin k}}\left(\frac{D_{c i}}{D_{c o}}\right)+\frac{D_{c i}}{2 \pi \lambda_{c}} \ln \frac{D_{c o}}{D_{c i}}}$

$L_{c}$ is the overall condenser length. The heat transfer coefficient, $h_{l c}$, is calculated from classical correlations by considering laminar flow for the sub-cooled condensate.

\subsubsection{Energy balance equations for the liquid line}

The energy balance at the liquid line is written as

$\dot{m} c_{p l}\left(T_{c o}-T_{c c i}\right)=G_{l} \frac{\left(T_{c o}-T_{c c i}\right)}{\ln \left(\frac{T_{c o}-T_{a m b}}{T_{c c i}-T_{a m b}}\right)}$

$\mathrm{T}_{\text {cci }}$ is the liquid temperature at the inlet of the compensation chamber. $\mathrm{G}_{\mathrm{I}}$ is the overall thermal conductance representing the heat transfer between the liquid and the ambient according to

$G_{l}=\frac{\pi D_{l i} L_{l}}{\frac{1}{h_{l l}}+\frac{1}{h_{a m b}}\left(\frac{D_{l i}}{D_{l o}}\right)+\frac{D_{l i}}{2 \pi \lambda_{w l}} \ln \frac{D_{l o}}{D_{l i}}}$

$L_{\|}$is the liquid line length. $D_{l i}$ and $D_{l o}$ are the inner and outer diameters of the liquid line, respectively. $h_{\|}$is the convective heat transfer coefficient between the wall and the liquid. It is calculated from classical correlations by considering the laminar flow regime.

\subsection{Determination of The Operating Modes in the LHP}

During normal operation of the LHP, two distinct operating modes are observed: the variable conductance operating mode (VCM) and the fixed conductance operating mode (FCM). These modes are identified by plotting the variations of the LHP operating temperature, which is generally the temperature of the compensation chamber, $T_{c c}$, as a function of the imposed power.

As can be seen in Figure 3, in the VCM mode, the condensation zone is short, and the condensate undergoes sub-cooling. When the heat input power increases, the operating temperature decreases. 
The LHP operates in this mode when the temperature at the outlet of the condenser, $T_{c o}$, is close to that of the heat sink, $T_{\text {sink. }}$. This is obtained when the sub-cooling zone is large. For this mode of operation, two curve profiles represent the variations in the operating temperature, $T_{c c}$, as a function of $Q_{i n}$ : The U-shape or the flattened shape. The profile depends on the distribution of the heat flux rate between the evaporator and the reservoir, the heat exchanges between the sub-cooled liquid in the liquid line and the ambient, and between the compensation chamber and the ambient. The leakage heat flux rate transferred by conduction through the evaporator wall and by convection through the porous medium can also influence the profile of the curve $T_{c c}=f\left(Q_{i n}\right)$. The operation in fixed conductance mode (FCM) is characterized by an almost linear increase of the operating temperature with the imposed power. The variations in the operating temperature depend mainly on the heat exchanges at the condenser and are less sensitive to the distribution of the leakage heat flux rate between the evaporator and the compensation chamber.

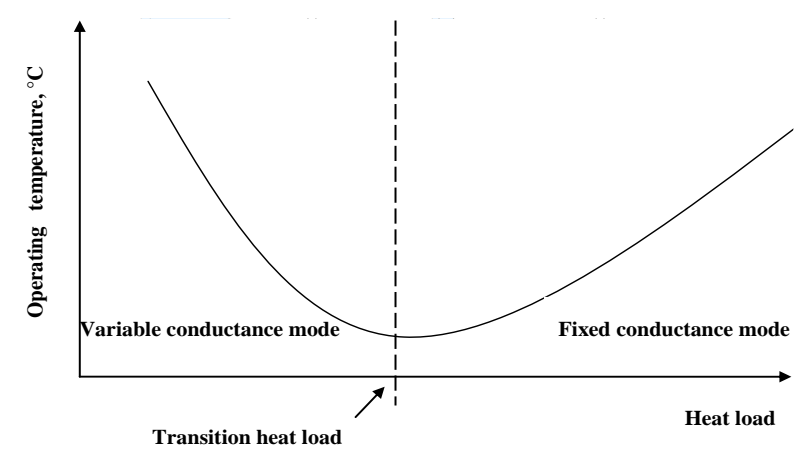

Fig. 3. The two operating modes of the LHP

To predict the thermal behavior of the LHP and facilitate the study of the influence of certain parameters, simplified equations for each mode of operation of the LHP are presented in this section and are deduced from the system of linear equations developed previously. Since the physical mechanisms acting on the LHP behavior during VCM and FCM are very different, two operatingtemperature expressions of $\mathrm{T}_{\mathrm{cc}}$ are proposed to describe the LHP operation [52]

$$
\begin{aligned}
T_{C C_{V C M}} & =\frac{T_{\text {sink }}+\frac{\Delta h_{v}}{C_{p l}}\left[\frac{G_{a x w}}{G_{e v}}+\frac{T_{a m b} G_{a m b c c}}{Q_{i n}}\right]+\left(T_{a m b}-T_{\operatorname{sink}}\right)\left[1-\exp \left(-\frac{G_{L}}{Q_{i n}} \frac{\Delta h_{v}}{c_{p l}}\right)\right]}{1-\frac{1}{Q_{i n}}\left[\frac{1}{\rho_{v} c_{p l}}\left(G_{c v}+G_{a x w}\right)\left(\Delta P_{l l}+\Delta P_{v l}+\Delta P_{v g}+\Delta P_{w}-\rho_{l} g \Delta H\right)-\frac{\Delta h_{v}}{c_{p l}} G_{a m b c c}\right]} \\
T_{C C_{F C M}} & =T_{\operatorname{sink}}+\frac{Q_{i n}}{G_{c}} \frac{1+\frac{G_{a x w}}{G_{e v}} \frac{G_{c} A_{s u b}}{G_{s u b} A_{C}}}{1+\frac{G_{a x w}}{G_{e v}}}
\end{aligned}
$$

The entire profile of $T_{c c}$ is deduced from the following equation

$$
T_{c c}=\max \left(T_{C C V C M}, T_{c C F C M}\right)
$$

\section{Detailed Analysis of The Heat Transfer in The Evaporator Section}

The heat transfer analysis of the LHP operation which is detailed in the previous section demonstrates the need for knowledge of the heat transfer coefficient of evaporation within the porous wick. As it is highlighted in the review study of the models which is presented in section 2 , the heat transfer coefficients of evaporation were calculated by expressions that are not valid for LHP 
operation or they are determined so that the experimental results fit those issued from the models. In this section, we propose to present a model that is capable of predicting the wall evaporator temperature and calculating the heat transfer coefficient of evaporation by assessing the experimental results based on dimensionless numbers.

The model considers the following assumptions: (1) a steady-state one-dimensional problem through the capillary structure, (2) the properties of the capillary structure are homogeneous, (3) the saturation temperature is constant throughout the capillary structure, and (4) the porous wick is considered completely saturated. To model the heat transfer within the primary wick, the energy balance can be represented by the heat diffusion equation with a source term according to Gabsi et al., [52]

$\frac{d^{2} T}{d x^{2}}-\frac{p_{e v}}{\lambda_{\text {peff }}}=0$

$\lambda_{\text {peff }}$ is the effective thermal conductivity of the porous structure. $p_{\text {ev }}$ is the heat source term per unit of volume due to evaporation within the porous structure. It can be written as

$p_{e v}=a A_{p}\left[T(x)-T_{v}\right]^{b}$

$a$ and $b$ are constants that can be determined experimentally. $A_{p}$ is the specific area per unit of the porous wick volume which is given by

$A_{p}=3\left(1-\varphi_{w}\right) / R_{p}$

where $R_{p}$ is the pore radius. The combination of Eq. (37) and Eq. (38) yields

$\frac{d^{2} T}{d x^{2}}-\frac{a A_{p}\left[T(x)-T_{v}\right]^{b}}{\lambda_{p e f f}}=0$

As the porous structure is considered thick and the specific area is large, the heat transfer throughout the capillary structure can be considered through a wall of semi-infinite thickness, and the expression of the temperature distribution within the wick is as follows

$\theta(x)=\left[\left(\frac{b-1}{2}\right) \sqrt{\frac{2 a A_{p}}{\lambda_{p e f f}(b+1)}} x+\theta_{e v}^{(1-b) / 2}\right]^{2 /(1-b)}$

where $\theta(x)=T(x)-T_{v}$ and $\theta_{e v}=T_{e v}-T_{v}$.

The net input heat flux serving for the evaporation, $\mathrm{q}_{\mathrm{ev}}$, obtained by excluding the axial thermal conduction and the heat losses to the ambient air, is equal to the heat flux transferred by evaporation within the porous structure $q_{\text {evp, }}$ and that transferred by conduction through the porous structure, $\mathrm{q}_{\mathrm{cd}}$. This energy balance can be written as:

$q_{e v}=q_{e v p}+q_{c d}=\varphi_{p} a \theta_{w}^{b}-\left.\lambda_{p e f f} \frac{d \theta}{d x}\right|_{x=0}$

The heat flux, $\mathrm{q}_{\mathrm{ev}}$, is calculated based on the heat transfer active area, $\mathrm{A}_{\mathrm{ev}}$, of the evaporator. By substituting Eq. (41) into Eq. (42), we obtain 
$q_{e v}=\varphi_{p} a \theta_{e v}{ }^{b}+\sqrt{\frac{2 a A_{p} \lambda_{p e f f}}{(b+1)}} \theta_{e v}^{(1+b) / 2}$

Knowing $\mathrm{q}_{\mathrm{ev}}, \mathrm{q}_{\mathrm{ev}}$ is calculated by iteration method and this needs the complete knowledge of the constants $\mathrm{a}$ and $\mathrm{b}$ which are determined experimentally. Gabsi et al., [52] developed a correlation based on the Vaschy-Bakingham theorem and led to the definition of dimensionless numbers containing the thermophysical properties of the working fluid and the geometrical parameters of the LHP. This correlation is written as follows

$N u=A \operatorname{Re}^{m} K p^{n} \operatorname{Pr}^{o} J a^{* p}$

$A^{*}, m, n, o$, and $p$ are coefficients. The Nusselt number, $\mathrm{Nu}$, is defined as follows

$N u=\frac{h_{e v} D_{g}}{\lambda_{l}}=\frac{Q_{e v} D_{g}}{\left(T_{e v}-T_{v}\right) A_{e v} \lambda_{l}}$

$A_{e v}$ is the heat exchange surface of the evaporator active area. $T_{e v}$ and $T_{v}$ are the evaporator wall and vapor temperatures, respectively. $D_{g}$ is the groove height. The Reynolds number is expressed as

$R e=\frac{\dot{m} D_{g}}{\mu_{l} A_{g}}=\frac{Q_{e v} D_{g}}{\Delta h_{v} \mu_{l} A_{g}}$

The Prandtl number is given by

$P_{r}=\frac{\mu_{l} c_{p l}}{\lambda_{l}}$

The dimensionless number, $\mathrm{K}_{\mathrm{p}}$, is the Kutateladze number calculated according to:

$K_{p}=\frac{P_{s a t} L a}{\sigma}$

La is the Laplace number defined as

$L a=\sqrt{\sigma / g\left(\rho_{l}-\rho_{v}\right)}$

The modified Jackob number is expressed as

$J_{a}^{*}=\frac{\rho_{l} c_{p l} T_{s a t}}{\rho_{v} \Delta h_{v}}$

The Nusselt number is calculated using the experimental values of $T_{e v}$ and $T_{v}$ as a function of the heat input power. The other dimensionless numbers are calculated by considering the thermophysical properties of the working fluid at the film temperature

$T_{f i l m}=\frac{T_{e v}+T_{v}}{2}$

The experimental value of the thermal resistance of the evaporator, $\mathrm{R}_{\mathrm{ev}}$, is calculated as follows 
$R_{e v}=\frac{T_{e v}-T_{v}}{Q_{e v}}$

The evaporation heat transfer coefficient, $h_{\mathrm{ev}}$, is then deduced from

$$
h_{e v}=\frac{1}{R_{e v} A_{e v}}
$$

Taking into account the different expressions of the dimensionless numbers and relation in Eq. (44), the expression of $Q_{e v}$ can be determined according to

$Q_{e v}=\left[\left(\lambda_{l} A_{e v} / D_{g}\right) \times A\left(D_{g} / \mu_{l} \Delta h_{v} A_{e v}\right)^{m} \times J a^{* n} \times K_{p}{ }^{p}\right]^{(1 / 1-m)}\left(T_{e v}-T_{v}\right)^{(1 / 1-m)}$

Given that $Q_{e v}=p_{e v} / A_{p}$ and compared with the Eq. (38), we deduce

$a=\left[\left(\lambda_{l} A_{e v} / D_{g}\right) \times A \times\left(D_{g} / \mu_{l} \Delta h_{v} A_{g}\right)^{m} \times\left(\rho_{l} C_{p l} T_{s a t} / \rho_{v} \Delta h_{v}\right)^{n}\left(P_{s a t} L a / \sigma\right)^{p}\right]^{(1 / 1-m)}$

$b=1 /(1-m)$

The thermal conductance, $\mathrm{G}_{\mathrm{sp}}$, is calculated according to

$G_{s p}=Q_{e v} / \theta_{e v}$

The coefficients of Eq. (44) are determined by a multiple linear regression for each heat sink temperature, $T_{\text {sink. }}$. The obtained values are listed in Table 6 . The coefficients $m$ and o are set to $2 / 3$ and 0 respectively to refine the results. Figure 4 represents the variations of the Nusselt number, $\mathrm{Nu}_{\text {cal, }}$ calculated from Eq. (44) as a function of that determined experimentally, $\mathrm{Nu}_{\text {exp }}$, based on the experimental values of the evaporation heat transfer coefficient, $\mathrm{h}_{\mathrm{ev}}$. It is noted that there is a good agreement between the experimental results and those obtained by the correlation for each $\mathrm{T}_{\text {sink. }}$. Indeed, the relative discrepancy between $\mathrm{Nu}_{\text {exp }}$ and $\mathrm{Nu}_{\text {cal }}$ varies between $\pm 10 \%$ for $\mathrm{T}_{\text {sink }}=80^{\circ} \mathrm{C}$ and $\pm 25 \%$ for $T_{\text {sink }}=20^{\circ} \mathrm{C}$. This correlation would allow refining the results of the model. Indeed, from this correlation, the thermal conductance of the evaporator, $\mathrm{G}_{\mathrm{ev}}$, can be determined to compute the temperature of the evaporator, $\mathrm{T}_{\mathrm{ev}}$, and that of the vapor, $\mathrm{T}_{\mathrm{v}}$.

Table 6

Coefficients of Eq. (44) for each sink temperature

\begin{tabular}{lllllll}
\hline $\mathrm{T}_{\text {sink }}\left({ }^{\circ} \mathrm{C}\right)$ & $\mathrm{m}$ & $\mathrm{n}$ & $\mathrm{o}$ & $\mathrm{p}$ & $\operatorname{Ln}(\mathrm{A})$ & $\begin{array}{l}\text { Relative discrepancy according } \\
\text { to the experiments }\end{array}$ \\
\hline 20 & $2 / 3$ & 4.757 & 0 & 3.050 & -44.173 & $\pm 25 \%$ \\
40 & $2 / 3$ & 4.160 & 0 & 2.916 & -39.337 & $\pm 25 \%$ \\
50 & $2 / 3$ & 8.224 & 0 & 5.105 & -77.540 & $\pm 25 \%$ \\
60 & $2 / 3$ & 6.469 & 0 & 4.605 & -63.086 & $\pm 20 \%$ \\
80 & $2 / 3$ & 4.290 & 0 & 3.707 & -43.467 & $\pm 10 \%$ \\
\hline
\end{tabular}



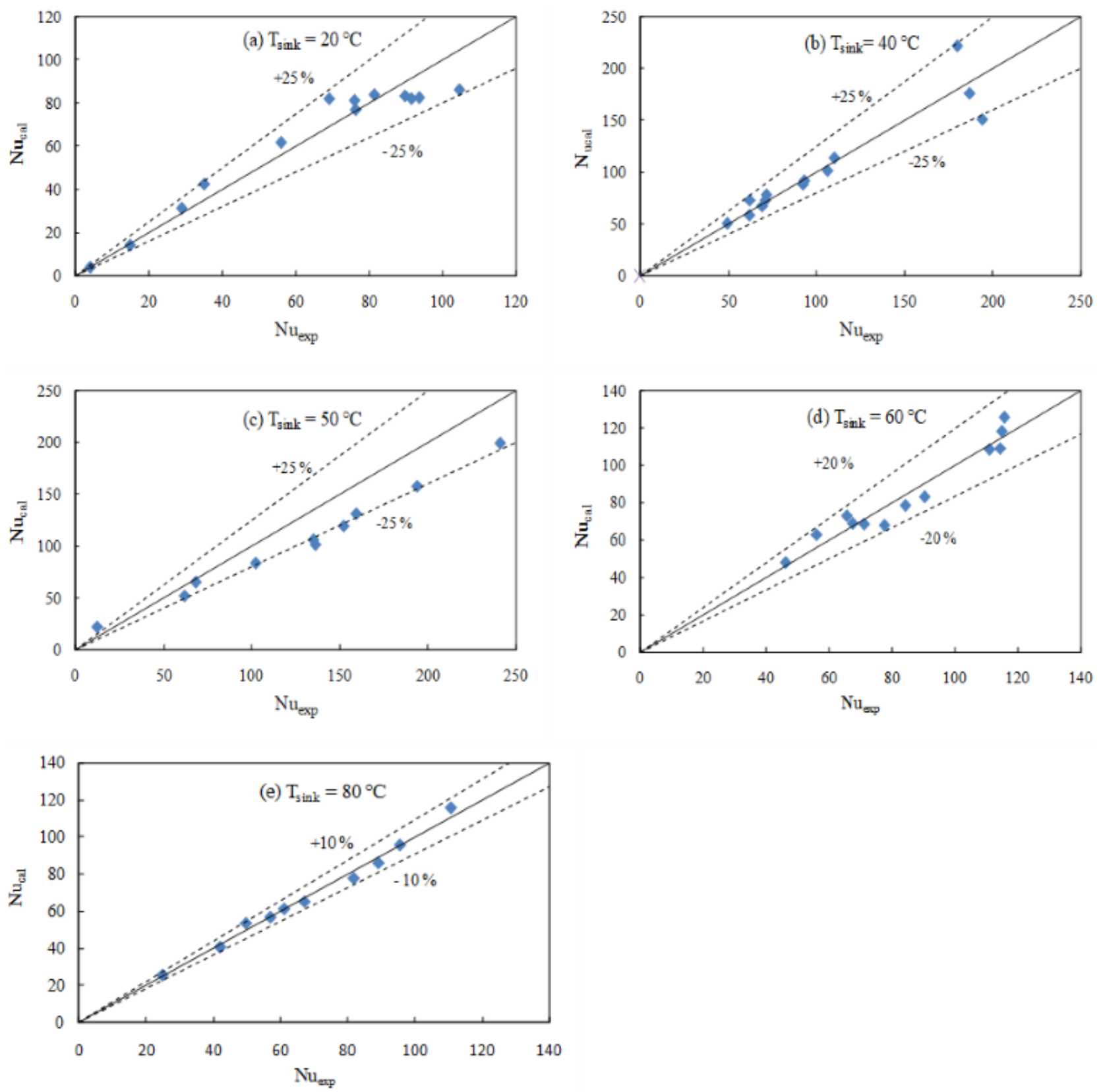

Fig. 4. Variations of $\mathrm{Nu}_{\text {cal }}$ versus $\mathrm{Nu}_{\text {exp }}$ for different heat sink temperatures: (a) $\mathrm{T}_{\text {sink }}=20^{\circ} \mathrm{C},(\mathrm{b}) \mathrm{T}_{\text {sink }}=40^{\circ} \mathrm{C}$, (c) $T_{\text {sink }}=50^{\circ} \mathrm{C}$, (d) $T_{\text {sink }}=60^{\circ} \mathrm{C}$, (e) $T_{\text {sink }}=60^{\circ} \mathrm{C}$, and (f) $T_{\text {sink }}=80^{\circ} \mathrm{C}$

\section{Model Validation}

\subsection{Validation for The Evaporator and Vapor Temperatures}

The variations of the evaporator and vapor temperatures obtained experimentally by Chernysheva et al., [26] are shown in Figure 5 for different heat sink temperatures, $T_{\text {sink }}=20,40$, and $50^{\circ} \mathrm{C}$. For these tests, the LHP is positioned horizontally. Table 7 shows the different values of $h_{\text {sink }}$ for each sink temperature calculated based on the indicated volume flow rate in the study of Maydanik et al., [27] using the Dittus-Boelter correlation [59]. The convective heat transfer coefficient between the LHP and the ambient is $h_{a m b}=10 \mathrm{~W} / \mathrm{m} . \mathrm{K}$ and the ambient temperature $\mathrm{T}_{\mathrm{amb}}=20^{\circ} \mathrm{C}$. 
Table 7

Values of $h_{\text {sink }}$ for each heat sink temperature

\begin{tabular}{llllll}
\hline $\mathrm{T}_{\text {sink }}\left({ }^{\circ} \mathrm{C}\right)$ & 20 & 40 & 50 & 60 & 80 \\
\hline $\mathrm{h}_{\text {sink }}\left(\mathrm{W} / \mathrm{m}^{2} . \mathrm{K}\right)$ & 9000 & 11893 & 13029 & 13981 & 15729 \\
\hline
\end{tabular}

For $\mathrm{T}_{\text {sink }}=20^{\circ} \mathrm{C}$, the LHP operates in VCM mode for heat loads lower than $150 \mathrm{~W}$ and FCM mode for heat input higher than $150 \mathrm{~W}$. It is noticed that the experimental values of the temperatures $\mathrm{T}_{\mathrm{ev}}$ and $T_{v}$ are higher than those obtained from the model (Figure 5(a) and Figure 5(b)). Hence, the model underestimates the experimental results for both modes. The discrepancy between the experimental results and those of the model can be explained experimentally by the generation of noncondensable gases in the compensation chamber and the condenser. Indeed, it is well known that the effect of non-condensable gases is effective for low heat sink temperatures, since, in these conditions, their volume is high, which alters the condensation phenomenon and the heat transfer in the compensation chamber. It is also noted that the gap between the experimental values and those resulting from the model increases for high input powers. This can be explained by the fact that these heat loads exceed the capillary limit $Q_{\max }$. Consequently, the porous capillary structure becomes starved of liquid, and dry-out happens. As a result, the temperatures $\left(T_{e v}\right.$ and $\left.T_{v}\right)$ increase excessively. As the model does not take into account the LHP operation in these particular conditions (presence of non-condensable gas and dry-out), the theoretical calculations do not retrieve the experimental values quantitatively but qualitatively since the model can predict the U-shape curve corresponding to the variations of the compensation chamber temperature with the heat load. Here, we can note that Chernysheva et al., [53] computed the theoretical calculations to retrieve the experimental variations of the vapor temperature as a function of the heat load for $T_{\text {sink }}=20^{\circ} \mathrm{C}$ for two LHPs: LHP\#1 and LHP\#2 (LHP\#1 is the same LHP considered in this study). The comparison between the experimental and computed results indicated that the calculated values underestimate the experimental ones in the VCM, as is found in this study.

For $\mathrm{T}_{\text {sink }}=40^{\circ} \mathrm{C}$, the LHP operates in the VCM mode for heat input power less than $100 \mathrm{~W}$ and the FCM mode for heat input powers ranging between 100 and $400 \mathrm{~W}$ (Figure 5(c) and Figure 5(d)). Here, the gap between the experimental values and the computed ones is reduced in both operating modes. However, for heat input powers higher than $400 \mathrm{~W}$, there is a rapid increase in $T_{e v}$ and $T_{v}$ leading to an increase in the gap between the computed temperatures by the model and those resulting from the experimental tests. Indeed, for these heat input powers, the capillary limit is exceeded, leading to the dry-out phenomenon. Here, again we can note that the comparison between the experimental vapor temperatures and the computed ones by Chernysheva et al., [53] shows a gap for the two operating modes. Indeed, the computed values underestimate the experimental ones.

For $\mathrm{T}_{\text {sink }}=50^{\circ} \mathrm{C}$, the LHP operates in VCM mode for heat input powers less than $50 \mathrm{~W}$ and FCM mode for heat input powers ranging between $50 \mathrm{~W}$ and $450 \mathrm{~W}$ (Figure 5(e) and Figure 5(f)). We also note that by increasing $T_{\text {sink, }}$, the heat input power range corresponding to the VCM mode decreases. The comparison between the calculated and the measured values of $T_{e v}$ and $T_{v}$ shows that there is a good agreement for a wide range of the heat input powers, except for heat loads above $450 \mathrm{~W}$, for which the discrepancy between the calculated and measured temperatures increases. For these heat input powers, the capillary limit is exceeded, and the dry-out occurs in the evaporator.

For $T_{\text {sink }}=60^{\circ} \mathrm{C}$, the LHP works only in FCM operating mode. Hence, a linear increase in the temperatures $T_{e v}$ and $T_{v}$ is obtained (Figure $5(\mathrm{~g})$ and Figure $5(\mathrm{~h})$ ). There is good agreement between the model and the experiment for heat input powers below $550 \mathrm{~W}$. Beyond this power, a gap between the calculated and the measured temperatures are observed, which shows that the capillary limit is reached and even exceeded. 
For $T_{\text {sink }}=80^{\circ} \mathrm{C}$, the temperature variations are linear, indicating that the LHP operates in FCM mode over the full heat input power range (Figure $5(\mathrm{i})$ and Figure $5(\mathrm{j})$ ). We note that there is a very satisfactory agreement between the model and the experiment for all the heat input powers. It should be noted that for this test, the capillary limit is not reached. Indeed, Chernysheva et al., [26] stopped the test at a power of $450 \mathrm{~W}$ before reaching the capillary limit, thus avoiding a high overpressure in the LHP since, under these conditions, the temperature of the vapor exceeds $100^{\circ} \mathrm{C}$.
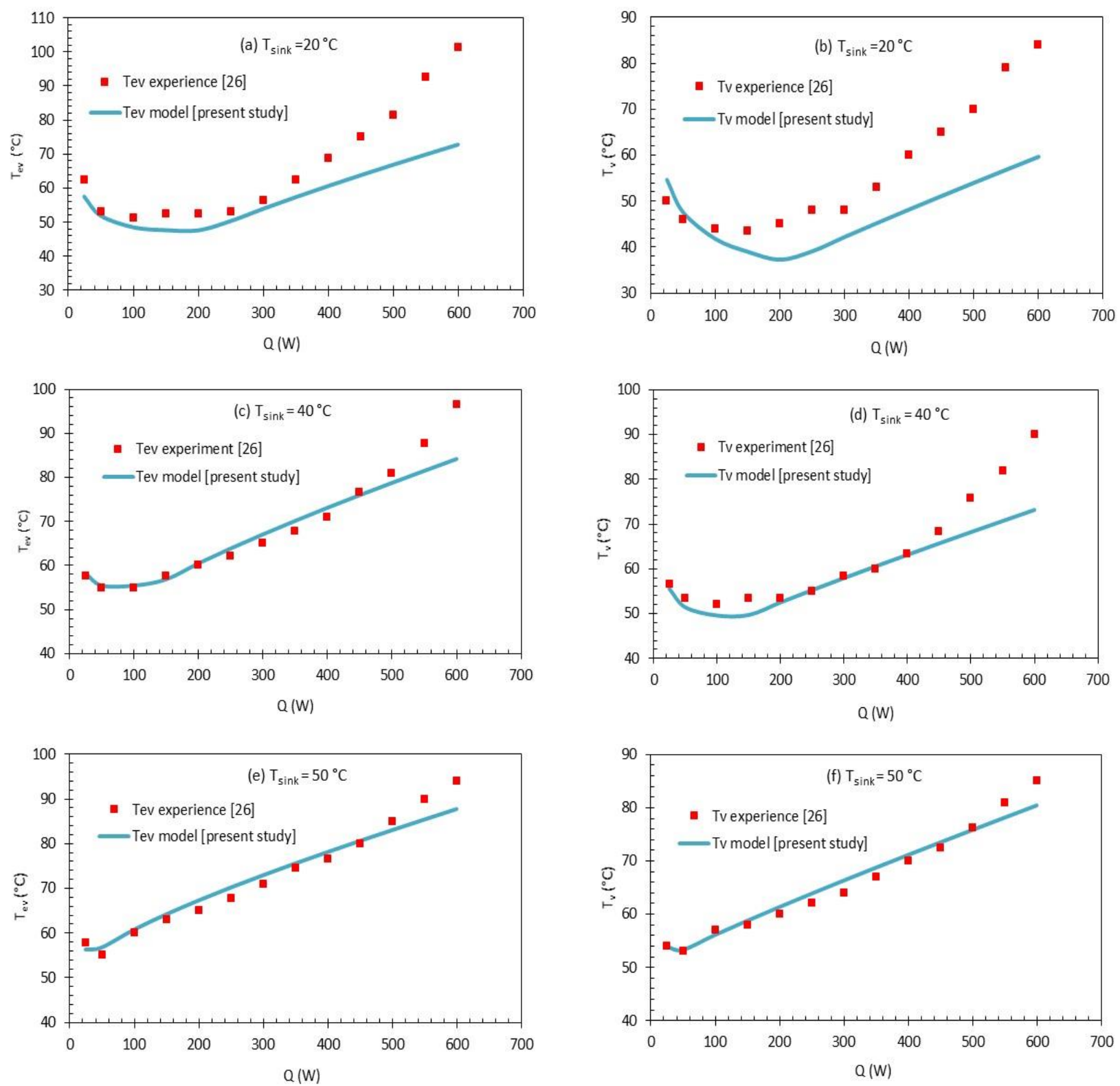

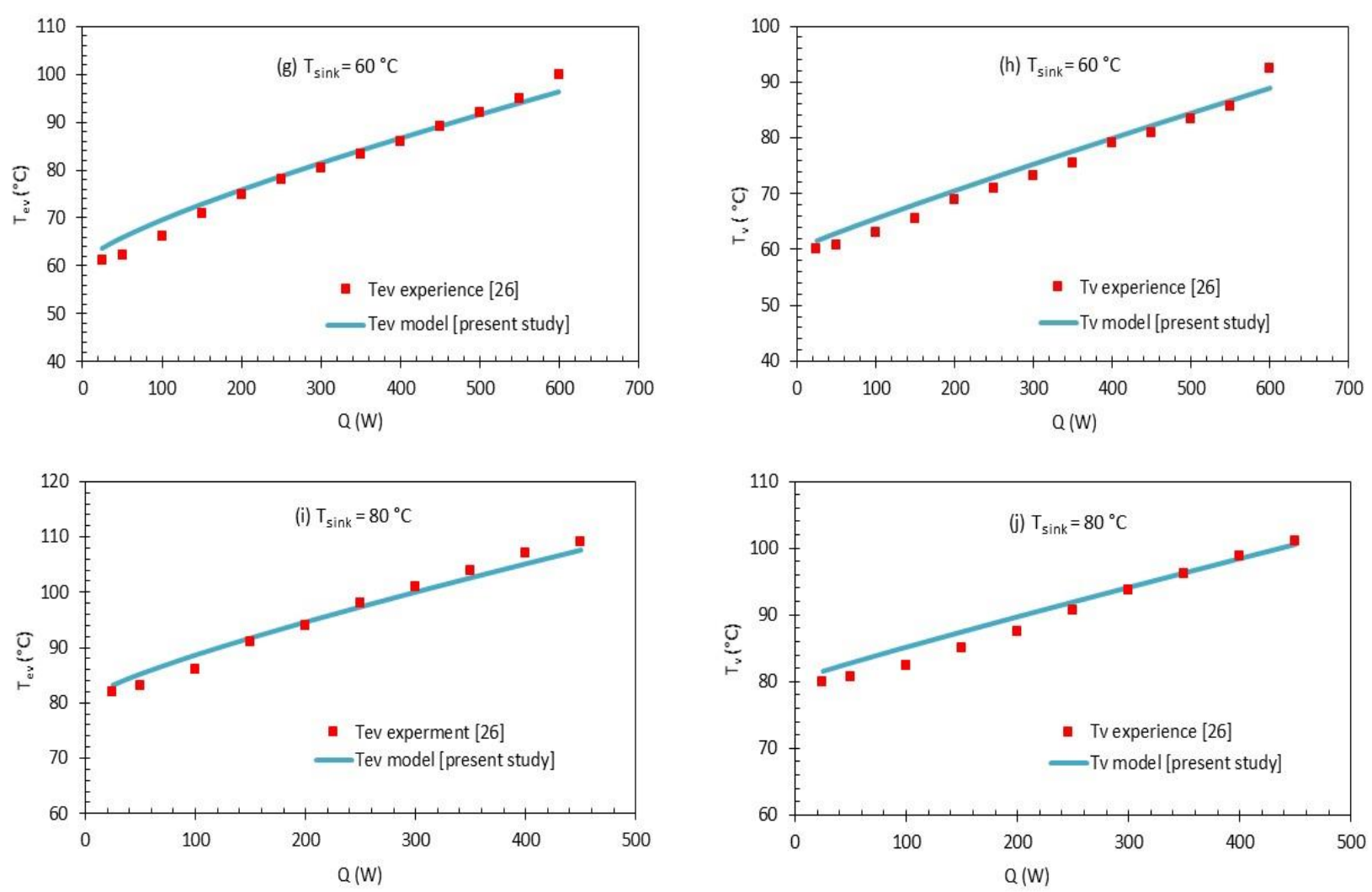

Fig. 5. Variations of the evaporator and vapor temperatures as a function of the heat load for various sink temperatures: (a)-(b) $\mathrm{T}_{\text {sink }}=20^{\circ} \mathrm{C}$, (c)-(d) $\mathrm{T}_{\text {sink }}=40^{\circ} \mathrm{C}$, (e)-(f) $\mathrm{T}_{\text {sink }}=5^{\circ} \mathrm{C}$, (g)-(h) $\mathrm{T}_{\text {sink }}=60^{\circ} \mathrm{C}$, and (i)-(j) $\mathrm{T}_{\text {sink }}=80^{\circ} \mathrm{C}$

Table 8 lists the values of the coefficient of correlation, $R^{2}$, which compares the experimental values of the evaporator and vapor temperatures to those computed by the model for different heat sink temperatures [26]. For the evaporator temperature, $R^{2}$ ranges between 0.953 and 0.998 ; however, for the vapor temperature, it varies between 0.953 and 0.997 for $T_{\text {sink }}$ ranging between 40 and $80^{\circ} \mathrm{C}$. The lowest $R^{2}$ is for $T_{\text {sink }}=20^{\circ} \mathrm{C}$ for the reasons indicated above.

\section{Table 8}

Values of $R^{2}$ for $T_{e v}$ and $T_{v}$ for each heat sink temperature

\begin{tabular}{llllll}
\hline$T_{\text {sink }}\left({ }^{\circ} \mathrm{C}\right)$ & 20 & 40 & 50 & 60 & 80 \\
\hline $\mathrm{R}^{2}$ for $\mathrm{T}_{\mathrm{v}}$ & 0.974 & 0.970 & 0.953 & 0.998 & 0.998 \\
$\mathrm{R}^{2}$ for $\mathrm{T}_{\mathrm{v}}$ & 0.850 & 0.954 & 0985 & 0.993 & 0.997 \\
\hline
\end{tabular}

\subsection{Validation for The Capillary Limit}

The expression of the capillary limit is given by Eq. (1). The capillary limit is calculated for different inclinations and is compared to the values computed by Chernysheva et al., [26]. It increases almost linearly as a function of the vapor temperature for different tilt angles. It can be noted that there is good agreement between the results of the proposed model and those computed by Chernysheva et al., [26] (Figure 6). Table 9 lists the values of the coefficient of correlation, $\mathrm{R}^{2}$, which compares the values computed by the model of Chernysheva et al., [26] to those computed by the present model, for different inclinations. $R^{2}$ varies between 0.994 and 0.998 for the considered tilt angle range. 
Table 9

Values of $R^{2}$ for $Q_{\max }$ for each inclination

\begin{tabular}{lllll}
\hline Inclination & $0^{\circ}$ & $10^{\circ}$ & $45^{\circ}$ & $60^{\circ}$ \\
$\mathrm{R}^{2}$ for $\mathrm{Q}_{\max }$ & 0.995 & 0.994 & 0.997 & 0.998 \\
\hline
\end{tabular}
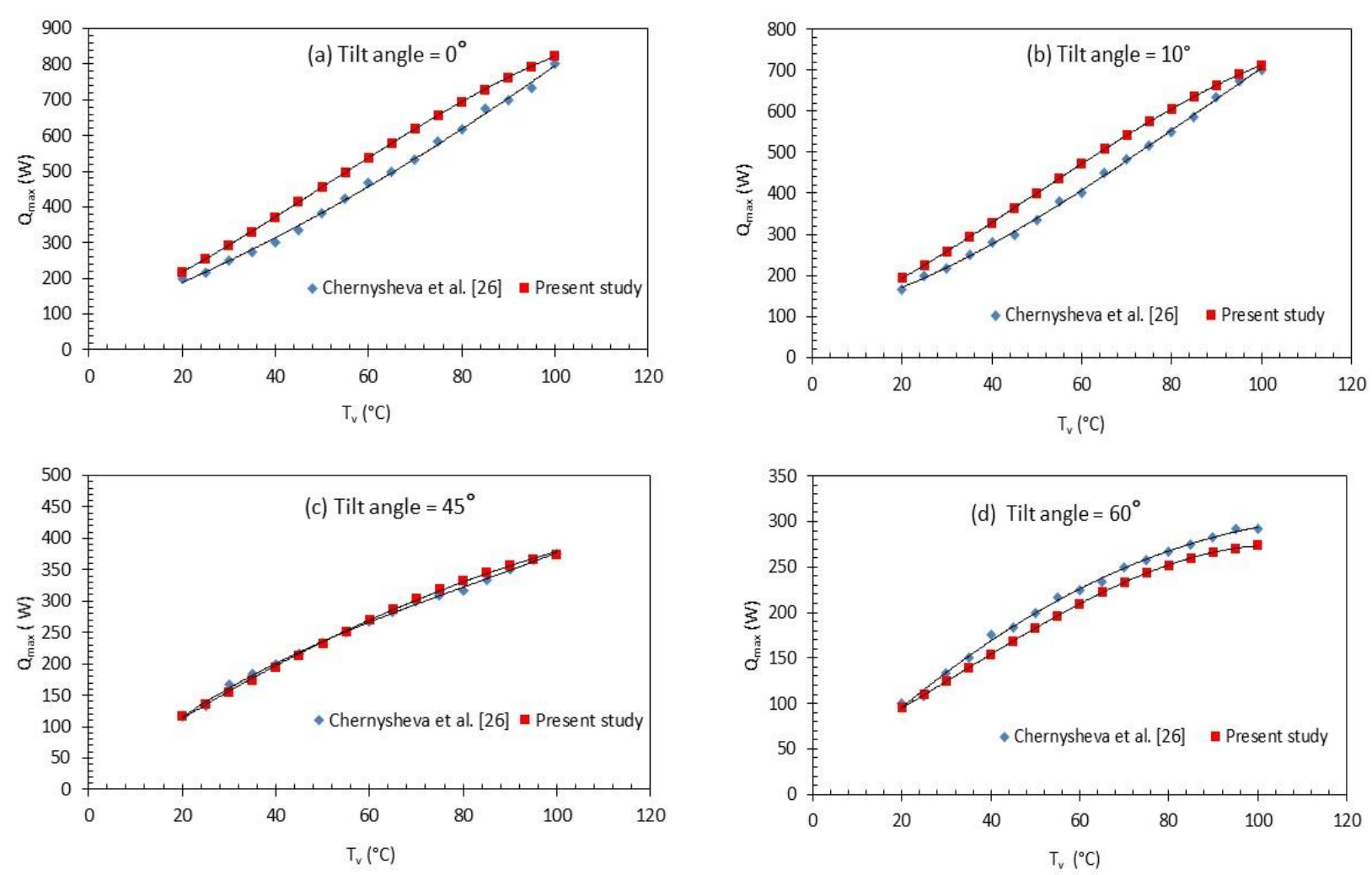

Fig. 6. Comparison between the capillary limit calculated from the proposed model and that of Chernysheva et al., [26] for different tilts: (a) $0^{\circ}$, (b) $10^{\circ}$, (c) $45^{\circ}$, and (d) $60^{\circ}$

\subsection{Validation for The Evaporator Thermal Resistance}

The experimental evaporator thermal resistance, $R_{\text {evexp, }}$ is deduced from the values of the evaporator wall and the vapor temperatures measured for each cooling temperature, $T_{\text {sink }}$ according to Eq. (52). The thermal resistance of the evaporator calculated by the model, $\mathrm{R}_{\text {evm, }}$ is deduced from Eq. (21). A comparison between the results of the experiments and those resulting from the model for different sink temperatures is shown in Figure 7. The curve showing the evolution of the evaporator thermal resistance as a function of the heat input power generally decreases in the VCM mode, which is characterized by the simultaneous decrease of $T_{e v}$ and $T_{v}$. Beyond the transition power, the thermal resistance of the evaporator becomes almost constant in the FCM mode. For $\mathrm{T}_{\text {sink }}$ $=20^{\circ} \mathrm{C}$, we notice that there is a large gap between $R_{\text {evexp }}$ and Revm, especially in the VCM operating mode. However, the gap between the experimental values and those computed from the proposed model for both operating modes becomes smaller for the other cooling temperatures. Generally, the computed values are closer to those obtained from the experiments, which proves the reliability of the proposed model for the evaporation phenomenon.

Table 10 lists the values of the coefficient of correlation, $R^{2}$, which compares the experimental values of Chernysheva et al., [26] to those computed by the present model for different sink temperatures. The values of $R^{2}$ are lower than those obtained for $T_{e v}$ and $T_{v}$. This can be explained by the experimental uncertainties in calculating $R_{\mathrm{ev}}$. Indeed, the highest gap between the experimental 
values of $R_{\mathrm{ev}}$ and the computed ones is obtained in the VCM operating mode, for which the heat loads and the difference $\left(T_{e v}-T_{v}\right)$ are low. Hence, the experimental uncertainties for this operating mode are high, especially for low heat sink temperatures.

Table 10

Values of $R^{2}$ for $R_{e v}$ for each heat sink temperature

\begin{tabular}{llllll}
\hline Inclination & $20^{\circ} \mathrm{C}$ & $40^{\circ} \mathrm{C}$ & $50^{\circ} \mathrm{C}$ & $60^{\circ} \mathrm{C}$ & $80^{\circ} \mathrm{C}$ \\
\hline$R^{2}$ for Rev & 0.840 & 0.855 & 0.876 & 0.810 & 0.971 \\
\hline
\end{tabular}
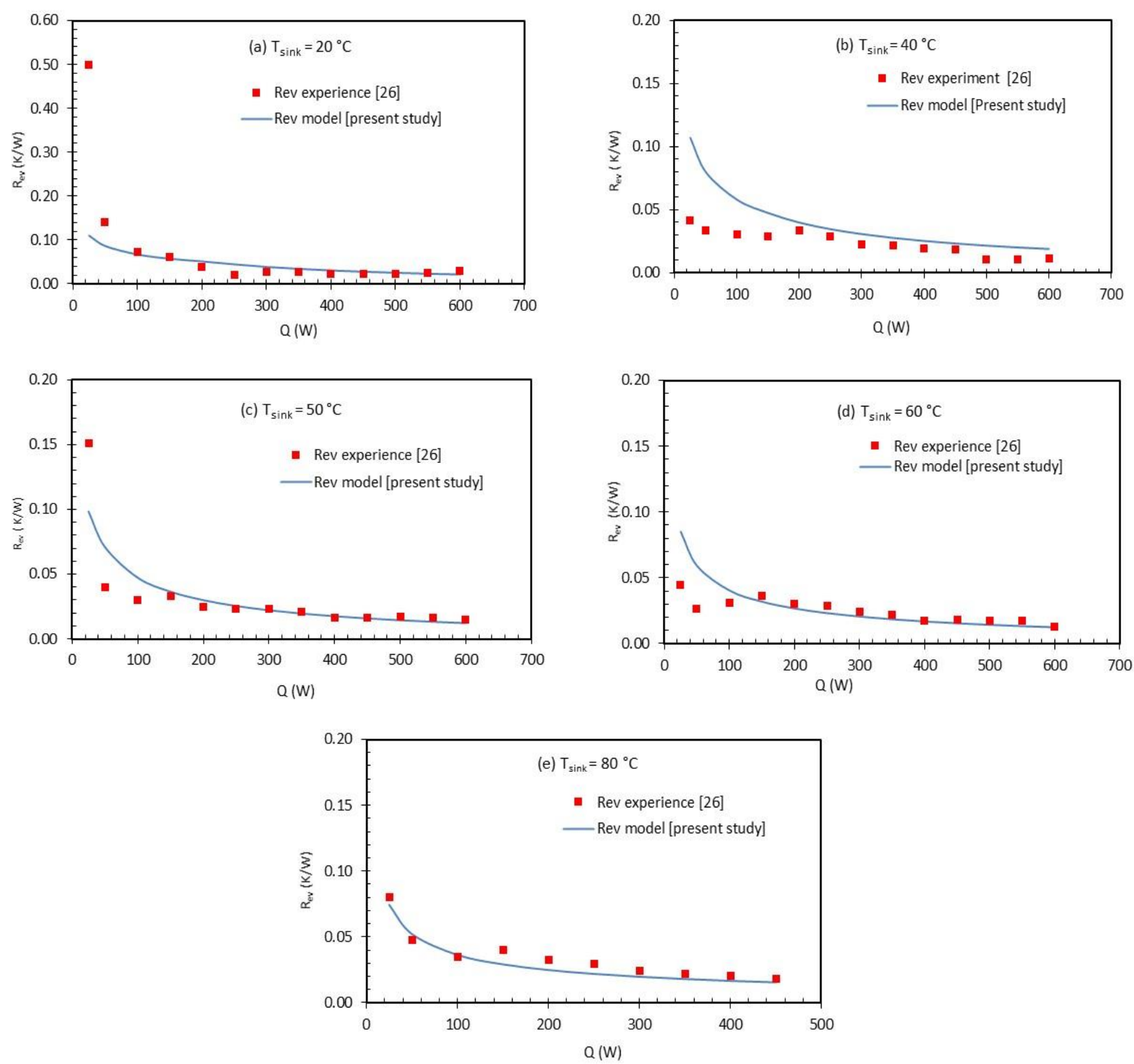

Fig. 7. Evaporator thermal resistances for different sink temperatures: (a) $T_{\text {sink }}=20^{\circ} \mathrm{C}$, (b) $T_{\text {sink }}=40^{\circ} \mathrm{C}$, (c) $T_{\text {sink }}=50^{\circ} \mathrm{C}$, (d) $T_{\text {sink }}=60^{\circ} \mathrm{C}$, (e) $T_{\text {sink }}=80^{\circ} \mathrm{C}$ 


\section{Parametric Study}

Several parameters can affect the thermal performance of the LHP, such as the orientation, the sink temperature, the ambient temperature, the heat exchange between the LHP and the ambient, the characteristics of the capillary structure (porosity and material), the dimensions of the grooves, the nature of the fluid, and how the heat is supplied to the evaporator. In what follows, we propose to study the effect of some parameters especially those related to the evaporator, such as the axial thermal conductance, $G_{a x w}$, which affects the heat leaks transferred by conduction between the evaporator and the compensation chamber. Furthermore, since the capillary structure plays an essential role in the LHP operation, we have proceeded to a parametric study, including the wick porosity and material, as well as the groove dimensions (width and depth). In this study, the ambient and sink temperatures are equal to respectively $20^{\circ} \mathrm{C}$ and $40^{\circ} \mathrm{C}$. The ambient and sink heat transfer coefficients are set as respectively 10 and $12,000 \mathrm{~W} / \mathrm{m}^{2} . \mathrm{K}$. The radius pore is equal to $27 \mu \mathrm{m}$, and the groove number is 12 .

\subsection{Effect of The Axial Thermal Conductance Between the Evaporator and The Compensation Chamber}

The variations of the evaporator and vapor temperatures as a function of the heat input power for different values of $G_{a x w}$ and $T_{\text {sink }}=40^{\circ} \mathrm{C}$ are shown in Figure 8. In these simulations, the porosity and the depth and width of the groove are equal to $0.46,1.8$, and $1.8 \mathrm{~mm}$, respectively. The capillary structure material is copper.

When the LHP operates in VCM mode, the heat flux rate serving to the evaporation decreases if the heat leaks transferred by thermal conduction between the evaporator and the compensation chamber walls increase (i.e., $G_{a x w}$ increases). Thus, the amount of vapor formed in the evaporator is reduced. Hence, the condensate, which leaves the condenser, is less sub-cooled when the axial heat leaks between the evaporator and the compensation chamber increase. As a result, the evaporator and vapor temperatures increase (Figure 8(a) and Figure 8(b)).

In the FCM operating mode, the mass of the vapor formed in the evaporator increases; However, the increase of the axial wall heat leaks between the evaporator and the compensation chamber reduces the vapor formation. Thus, the excess of the vapor produced by the increase of the imposed power is compensated by a mass defect of the vapor induced by the axial wall heat leaks. Consequently, the combined effect of both the heat load increase and the axial wall heat leaks hardly affects the amount of the condensate formed in the condenser, and the length of the sub-cooling zone is not so affected. Thus, the temperatures of the condensate at the outlet of the condenser and the inlet of the compensation chamber are hardly affected by this combined effect since the pressure losses in the liquid line are not affected so much. Therefore, the temperature of the evaporator and that of the vapor are barely affected by the axial wall heat leaks. The capillary limit, which constitutes the maximum heat input beyond which dry-out starts, increases with the axial thermal conductance between the evaporator and the compensation chamber, $\mathrm{G}_{\mathrm{axw}}$. Indeed, the rise of the vapor temperature level in the LHP due to the $G_{a x w}$ increase causes a reduction of the vapor pressure drop in the grooves $\Delta \mathrm{P}_{\mathrm{vg}}$ since the vapor dynamic viscosity decreases. Hence, the driving capillary pressure, $\Delta \mathrm{P}_{\text {cap }}$, can overcome the pressure drops easily, and consequently, the capillary limit increases. The capillary limits for $\mathrm{G}_{\mathrm{axw}}=0.45,0.56$, and $0.67 \mathrm{~W} / \mathrm{K}$ are 480,485 , and $490 \mathrm{~W}$, respectively. The heat input powers which are considered in the simulations are limited to the capillary limits since the model does not take into account the dry-out phenomenon in the mathematical formulation. 


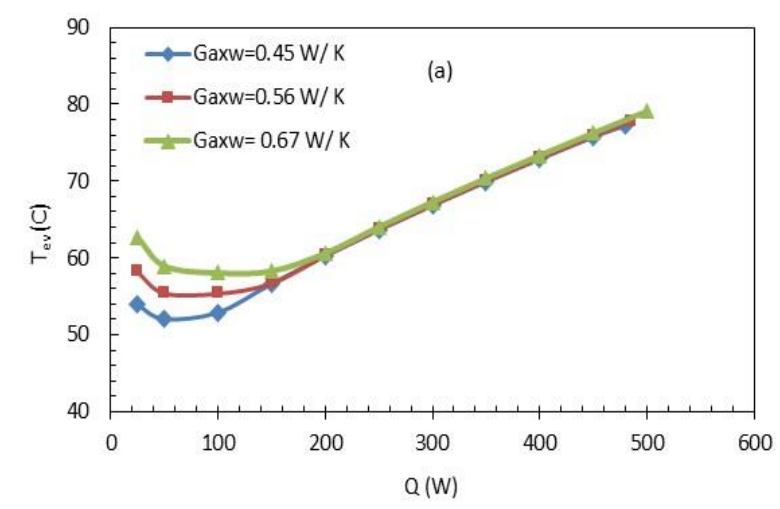

Fig. 8. Temperature variations for differen: values of $G_{\text {axw: }}$ (a) evaporator temperature, (b) vapor temperature

\subsection{Effect of The Capillary Structure Porosity}

The variations of the evaporator and vapor temperatures as a function of the heat input power, for different porosities $\left(T_{\text {sink }}=40^{\circ} \mathrm{C}\right)$ are shown in Figure 9 . In these simulations, the groove depth and width are both equal to $1.8 \mathrm{~mm}$ and the conductance $G_{a x w}$ is equal respectively to $0.67 \mathrm{~W} / \mathrm{K}$. The material used for the capillary structure is copper.
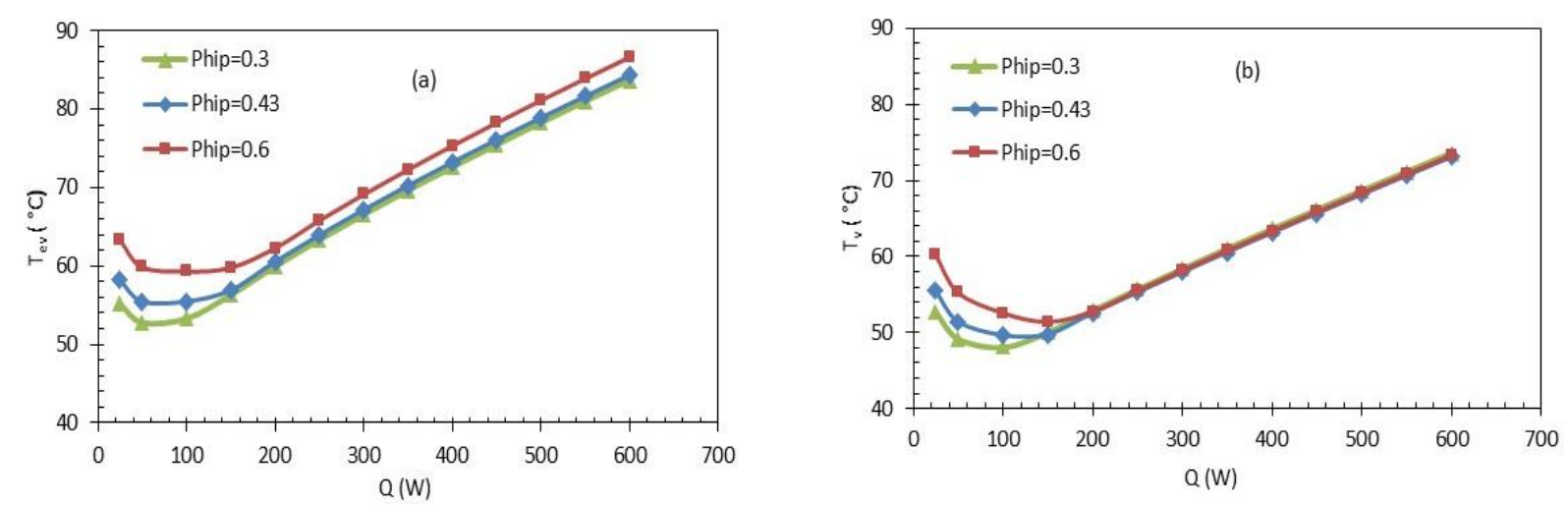

Fig. 9. Temperature variations for different porosities: (a) evaporator temperature, (b) vapor temperature

In the VCM operating mode, the evaporator and vapor temperatures increase with porosity; however, for the FCM operating mode, the evaporator and vapor temperatures are hardly affected by porosity. In the VCM operating mode, as the porosity increases, the effective thermal conductivity of the porous structure decreases, which leads to an increase in the evaporator thermal resistance. Thus, for an imposed heat input power, the evaporator temperature increases with porosity (Figure 9(a)). Besides, when porosity increases for an imposed heat input power, the amount of liquid coming from the compensation chamber augments due to the permeability of the capillary structure increase with porosity. Thus, the evaporation is intensified, causing an increase in the mass of the vapor and its temperature (Figure 9(b)). In the FCM operating mode, the imposed powers being much higher than those of the VCM operating mode, the vapor mass-produced in the evaporator is high. Thus, for a given power, the increase in the vapor mass with the porosity is not significant compared to that induced by the heat load increase, and consequently, the evaporator and vapor temperatures are not affected so much by the porosity increase. It is worth noting that augmenting the porosity causes a reduction in the vapor pressure drop in the grooves. Consequently, the capillary driving pressure 
can overcome the pressure drops easily, and the capillary limit is increased. Hence, the capillary limits for $\varphi_{p}=0.3,0.4$, and 0.46 are 100,330 , and $485 \mathrm{~W}$, respectively.

\subsection{Effect of The Capillary Structure Material}

The variations of the evaporator and the vapor temperatures as a function of the heat load for different capillary structure materials: $\operatorname{copper}\left(\lambda_{\text {copper }}=390 \mathrm{~W} / \mathrm{m} . \mathrm{K}\right)$ and nickel $\left(\lambda_{\text {nickel }}=90 \mathrm{~W} / \mathrm{m} . \mathrm{K}\right)$ are depicted in Figure 10. The porosity and the conductance $\mathrm{G}_{\text {axw }}$ are equal to respectively 0.46 and 0.67 $\mathrm{W} / \mathrm{m}^{2}$. Both the groove depth and width are equal to $1.8 \mathrm{~mm}$.

The nature of the material affects the evaporator temperature for both operation modes (Figure 10(b)). The use of a capillary structure made in nickel leads to high evaporator temperatures compared to those obtained with copper. The vapor temperature is sensitive to the capillary structure material in the VCM mode. However, it is not substantially affected by this parameter in FCM operating mode. The transition power increases with the decrease of the capillary structure's thermal conductivity. Indeed, for nickel and copper, the transition power is 200 and $100 \mathrm{~W}$, respectively.
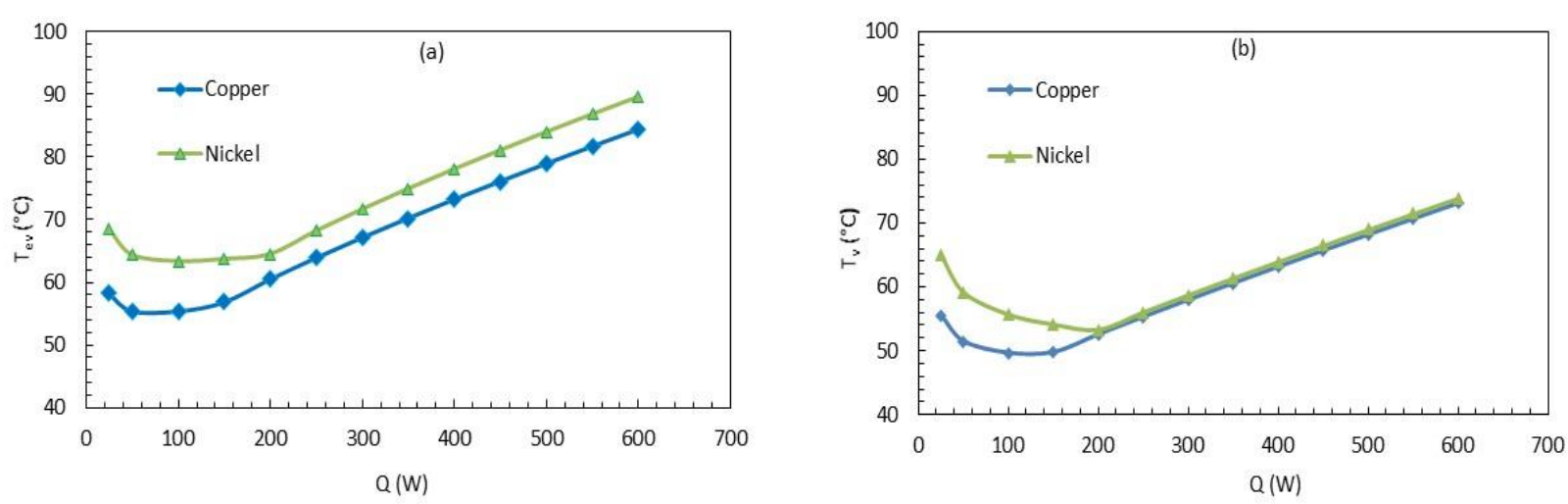

Fig. 10. Temperature variations for different capillary structure materials: (a) evaporator temperature,

(b) vapor temperature

The evaporator temperature increase is due to that of the evaporator thermal resistance caused by the decrease of the capillary structure thermal conductivity (Figure 10(a)). Likewise, the use of a low conducting material augments the axial heat leaks transferred by conduction between the evaporator wall and the compensation chamber wall, thus reducing the heat flux rates necessary for the evaporation of the liquid in the capillary structure. The decrease of the temperature in the LHP due to the increase of the capillary structure thermal conductivity reduces the pressure drops since the dynamic viscosity decreases with temperature. Hence, the driving capillary pressure overcomes the pressure drops easily. Consequently, the capillary limit is increased. The capillary limits for copper and nickel are 485 and $525 \mathrm{~W}$, respectively.

\subsection{Effect of The Groove Dimensions}

The variations of the evaporator and vapor temperatures as a function of the imposed power for different groove depths, $D_{g}$, are shown in Figure 11. For these simulations, $W_{\mathrm{g}}$ is equal to $1.8 \mathrm{~mm}$. The values of the porosity and $\mathrm{G}_{\mathrm{axw}}$ are respectively 0.46 and $0.67 \mathrm{~W} / \mathrm{K}$. Copper is the capillary structure material. 
In VCM mode, these temperatures increase with the groove depth; nevertheless, in FCM mode, the groove depth hardly affects the evaporator and the vapor temperatures. In VCM mode, and for a given heat load, the evaporator temperature increase with the groove depth is mainly due to the augmentation of the conductive thermal resistance, which can reduce the heat flux rate necessary for the evaporation within the capillary structure. This also increases the vapor temperature. In FCM mode, the depth of the grooves does not affect the temperature levels since the heat transfer in this operation mode is controlled by the heat sink. It can also be noticed that the transition power increases slightly with the groove depth. The amount of vapor formed in the grooves due to the evaporation is reduced when the depth of the grooves increases. Consequently, the vapor pressure drops in the grooves decrease. Hence, the driving capillary pressure can overcome all the pressure drops easily, causing an increase in the capillary limit. The capillary limits for $D_{g}=1,1.8$, and $2.5 \mathrm{~mm}$ are 240,485 , and $750 \mathrm{~W}$, respectively.
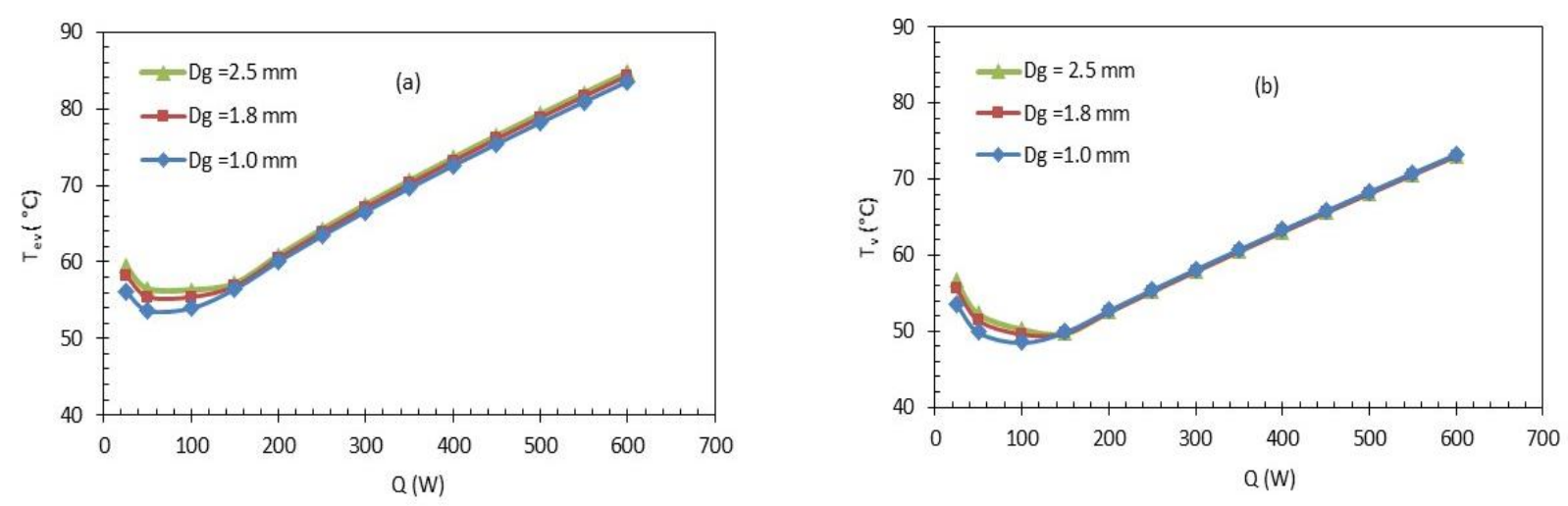

Fig. 11. Effect of the groove depth on (a) the evaporator temperature and (b) the vapor temperature

The effect of the groove width, $W_{g}$, on the evaporator, and vapor temperatures are shown in Figure 12. In these simulations, $D_{g}$ is fixed to $1.8 \mathrm{~mm}$. The increase of the groove width causes a slight decrease in these temperatures. Indeed, to preserve the number of grooves, as the width of the groove increases, the groove spacing decreases. Thus, there is less material, and the conductive heat transfer decreases in favor of the heat transfer by phase change. The reduction of the temperature level due to the decrease of the groove width is obvious in the VCM. Indeed, the amount of vapor formed in the VCM is usually not important, and with the reduction of the heat flux responsible for the evaporation of the liquid, the effect of the $W_{g}$ becomes more noticeable. Consequently, the power transition increases when the groove width increases.
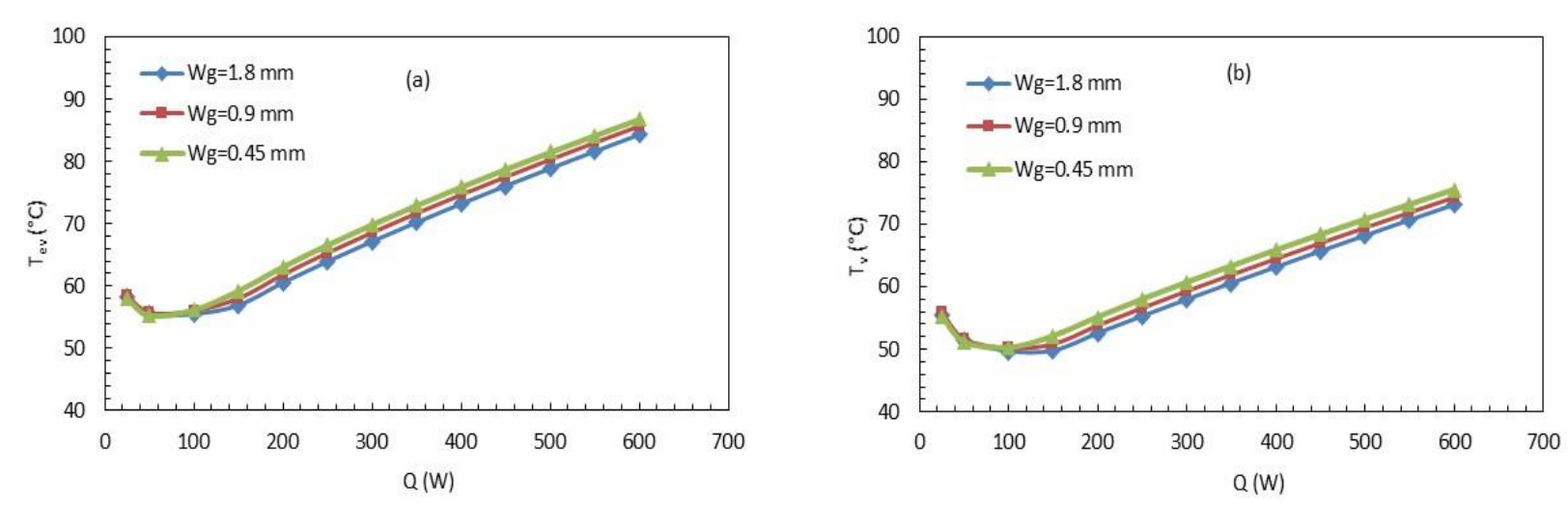

Fig. 12. Effect of the groove width on (a) the evaporator temperature and (b) the vapor temperature 
The effect of the groove width on the capillary limit is the same as that of the groove depth. Indeed, the increase of $\mathrm{W}_{\mathrm{g}}$ induces the reduction of the groove spacing $\mathrm{S}_{\mathrm{g}}$. Accordingly, the heat exchange area is reduced. This influences the heat flux rate responsible for the evaporation of the liquid within the sintered powder, which is reduced. The amount of vapor formed in the grooves is not important for large groove width, and consequently, the vapor pressure drop in the grooves is reduced. Since the other pressure drops in the LHP are not affected by $\mathrm{W}_{\mathrm{g}}$, the capillary pressure can overcome these pressure drops easily. The capillary limits for $W_{g}=0.45,0.9$, and $1.8 \mathrm{~mm}$ are 90,250 , and $485 \mathrm{~W}$, respectively.

\section{Conclusion}

In this paper, an analytical model of an LHP has been developed in steady-state operation. It is based on mass, momentum, and energy balance equations, as well as the thermodynamic relationships. The model allows calculating the temperature of the LHP components and the pressure losses for different operating conditions and different geometrical characteristics of the LHP. The heat transfer device used for the simulations is a copper-water LHP with a flat-evaporator tested by Chernysheva et al., [26] for heat loads ranging from 5 to $600 \mathrm{~W}$ at a horizontal position. A satisfactory agreement was found between the computed and experimental results.

A parametric study, including the effects of the axial conductive heat leaks, porosity, the material of the capillary structure, and the groove dimensions, was carried out. The results are summarized in Table 11. The effects of the studied parameters on the LHP thermal performances are different according to the operating modes.

Table 11

\begin{tabular}{lll}
\multicolumn{3}{l}{ Summary of the effect of the studied parameters } \\
\hline Parameter Trend & VCM Mode & FCM Mode \\
\hline Gaxw increases & $T_{e v} \& T_{v}$ increase & $T_{e v} \& T_{v}$ not affected \\
Porosity increases & $T_{e v} \& T_{v}$ increase & $T_{e v}$ increases \& $T_{v}$ not affected \\
Wick thermal conductivity increases & $T_{e v} \& T_{v}$ decrease & $T_{e v}$ decreases \& $T_{v}$ not affected \\
$D_{g}$ increases & $T_{e v} \& T_{v}$ increase & $T_{e v} \& T_{v}$ not affected \\
$W_{g}$ increases & $T_{e v} \& T_{v}$ not affected & $T_{e v} \& T_{v}$ decrease \\
\hline
\end{tabular}

For the VCM operating mode, the increase of the heat leaks by conduction between the evaporator and the compensation chamber, porosity, and the groove depth lead to the augmentation of the evaporator and vapor temperatures; However, increasing the wick thermal conductivity occasions a reduction of these temperatures. It is noteworthy that increasing the groove width hardly affects the evaporator and vapor temperatures.

For the FCM operating mode, the evaporator and vapor temperatures are not affected by the conductive heat leaks between the evaporator and the compensation chamber as well as the groove depth. Furthermore, the vapor temperature is not affected by the porosity and the wick thermal conductivity; however, the evaporator temperature increases with the first parameter and decreases with the second one. Increasing the groove width in the FCM operating mode occasions a decrease in the evaporator and vapor temperatures.

The present work proposes an original method that consists of using dimensional analysis to determine the evaporation heat transfer coefficient from the model and it also proposes original modeling of the phenomenon of evaporation in LHPs. The study aims to model the operation of an LHP in a steady-state regime to determine its thermal performance (capillary limit, thermal resistance, and temperature of the evaporator) for different operating conditions (input power, the 
temperature of the cold source, ambient temperature, convection with the ambient, thermal leaks to the compensation chamber, and gravity) as a function of the geometric parameters (diameters and lengths of the liquid and vapor lines, condensation surface, and width and depth of the grooves) and the properties of the capillary structure (porosity, material, and permeability).

\section{References}

[1] Hodot, Romain, Valérie Sartre, Frédéric Lefèvre, and Claude Sarno. "Modeling and experimental tests of a loop heat pipe for aerospace applications." Journal of Thermophysics and Heat Transfer 30, no. 1 (2016): $182-191$. https://doi.org/10.2514/1.T4551

[2] Sarno, C., C. Tantolin, R. Hodot, Yu Maydanik, and S. Vershinin. "Loop thermosyphon thermal management of the avionics of an in-flight entertainment system." Applied Thermal Engineering 51, no. 1-2 (2013): 764-769. https://doi.org/10.1016/i.applthermaleng.2012.10.012

[3] Singh, Randeep, Aliakbar Akbarzadeh, Chris Dixon, Mastaka Mochizuki, and Roger R. Riehl. "Miniature loop heat pipe with flat evaporator for cooling computer CPU." IEEE Transactions on Components and Packaging Technologies 30, no. 1 (2007): 42-49. https://doi.org/10.1109/TCAPT.2007.892066

[4] Singh, Randeep, Aliakbar Akbarzadeh, and Masataka Mochizuki. "Operational characteristics of a miniature loop heat pipe with flat evaporator." International Journal of Thermal Sciences 47, no. 11 (2008): 1504-1515. https://doi.org/10.1016/j.ijthermalsci.2007.12.013

[5] Singh, Randeep, Aliakbar Akbarzadeh, and Masataka Mochizuki. "Effect of wick characteristics on the thermal performance of the miniature loop heat pipe." Journal of Heat Transfer 131, no. 8 (2009). https://doi.org/10.1115/1.3109994

[6] Singh, Randeep, Aliakbar Akbarzadeh, and Masataka Mochizuki. "Operational characteristics of the miniature loop heat pipe with non-condensable gases." International Journal of Heat and Mass Transfer 53, no. 17-18 (2010): 34713482. https://doi.org/10.1016/j.ijheatmasstransfer.2010.04.008

[7] Celata, Gian Piero, Maurizio Cumo, and Massimo Furrer. "Experimental tests of a stainless steel loop heat pipe with flat evaporator." Experimental Thermal and Fluid Science 34, no. 7 (2010): 866-878. https://doi.org/10.1016/i.expthermflusci.2010.02.001

[8] Li, Ji, Daming Wang, and G. P. Peterson. "Experimental studies on a high performance compact loop heat pipe with a square flat evaporator." Applied Thermal Engineering 30, no. 6-7 (2010): 741-752.

[9] Adoni, Abhijit Avinash, Amrit Ambirajan, V. S. Jasvanth, Dinesh Kumar, and Pradip Dutta. "Theoretical and experimental studies on an ammonia-based loop heat pipe with a flat evaporator." IEEE Transactions on Components and Packaging Technologies 33, no. 2 (2010): 478-487. https://doi.org/10.1109/TCAPT.2010.2042056

[10] Liu, Zhichun, Dongxing Gai, Huan Li, Wei Liu, Jinguo Yang, and Mengmeng Liu. "Investigation of impact of different working fluids on the operational characteristics of miniature LHP with flat evaporator." Applied Thermal Engineering 31, no. 16 (2011): 3387-3392. https://doi.org/10.1016/i.applthermaleng.2011.06.023

[11] Nguyen, Xuan Hung, Byung Ho Sung, Jeehoon Choi, Seong Ryoul Ryoo, Han Seo Ko, and Chulju Kim. "Study on heat transfer performance for loop heat pipe with circular flat evaporator." International Journal of Heat and Mass Transfer 55, no. 4 (2012): 1304-1315. https://doi.org/10.1016/j.ijheatmasstransfer.2011.09.010

[12] Joung, Wukchul, Keesool Gam, Kwangmin Park, Sungpil Ma, and Jinho Lee. "Transient responses of the flat evaporator loop heat pipe." International Journal of Heat and Mass Transfer 57, no. 1 (2013): $131-141$. https://doi.org/10.1016/j.ijheatmasstransfer.2012.10.025

[13] Wang, Dongdong, Zhichun Liu, Song He, Jinguo Yang, and Wei Liu. "Operational characteristics of a loop heat pipe with a flat evaporator and two primary biporous wicks." International Journal of Heat and Mass Transfer 89 (2015): 33-41. https://doi.org/10.1016/i.ijheatmasstransfer.2015.05.042

[14] Xu, Jiayin, Zhiyuan Wang, Hong Xu, and Li Zhang. "Experimental research on the heat performance of a flat copperwater loop heat pipe with different inventories." Experimental Thermal and Fluid Science 84 (2017): 110-119. https://doi.org/10.1016/i.expthermflusci.2017.02.003

[15] He, Song, Jing Zhao, Zhi-chun Liu, Wei Tian, Jin-guo Yang, and Wei Liu. "Experimental investigation of loop heat pipe with a large squared evaporator for cooling electronics." Applied Thermal Engineering 144 (2018): 383-391. https://doi.org/10.1016/i.applthermaleng.2018.08.075

[16] Anand, A. R., Akhil Jaiswal, Amrit Ambirajan, and Pradip Dutta. "Experimental studies on a miniature loop heat pipe with flat evaporator with various working fluids." Applied Thermal Engineering 144 (2018): 495-503. https://doi.org/10.1016/i.applthermaleng.2018.08.092 
[17] Zhang, Yixue, Junyu Liu, Longfei Liu, Haolin Jiang, and Tao Luan. "Numerical simulation and analysis of heat leakage reduction in loop heat pipe with carbon fiber capillary wick." International Journal of Thermal Sciences 146 (2019): 106100.

[18] Singh, Randeep, Aliakbar Akbarzadeh, Chris Dixon, and Masataka Mochizuki. "Novel design of a miniature loop heat pipe evaporator for electronic cooling." Journal of Heat Transfer 129 (2007): 1445-1452. https://doi.org/10.1115/1.2754945

[19] Joung, Wukchul, Taeu Yu, and Jinho Lee. "Experimental study on the loop heat pipe with a planar bifacial wick structure." International Journal of Heat and Mass Transfer 51, no. 7-8 (2008): $1573-1581$. https://doi.org/10.1016/i.ijheatmasstransfer.2007.07.048

[20] Joung, Wukchul, Taeu Yu, and Jinho Lee. "Experimental study on the operating characteristics of a flat bifacial evaporator loop heat pipe." International Journal of Heat and Mass Transfer 53, no. 1-3 (2010): $276-285$. https://doi.org/10.1016/i.ijheatmasstransfer.2009.09.031

[21] Maydanik, Yu, S. Vershinin, M. Chernysheva, and S. Yushakova. "Investigation of a compact copper-water loop heap pipe with a flat evaporator." Applied Thermal Engineering 31, no. 16 (2011): 3533-3541. https://doi.org/10.1016/i.applthermaleng.2011.07.008

[22] Becker, Suzanne, S. Vershinin, V. Sartre, E. Laurien, Jocelyn Bonjour, and Yu F. Maydanik. "Steady state operation of a copper-water LHP with a flat-oval evaporator." Applied Thermal Engineering 31, no. 5 (2011): 686-695. https://doi.org/10.1016/j.applthermaleng.2010.02.005

[23] Zhang, Xianfeng, Jiepeng Huo, and Shuangfeng Wang. "Experimental investigation on temperature oscillation in a miniature loop heat pipe with flat evaporator." Experimental Thermal and Fluid Science 37 (2012): 29-36. https://doi.org/10.1016/i.expthermflusci.2011.09.010

[24] Wang, Shuangfeng, Jiepeng Huo, Xianfeng Zhang, and Zirong Lin. "Experimental study on operating parameters of miniature loop heat pipe with flat evaporator." Applied Thermal Engineering 40 (2012): 318-325. https://doi.org/10.1016/i.applthermaleng.2012.02.029

[25] Choi, Jeehoon, Wataru Sano, Weijie Zhang, Yuan Yuan, Yunkeun Lee, and Diana-Andra Borca-Tasciuc. "Experimental investigation on sintered porous wicks for miniature loop heat pipe applications." Experimental Thermal and Fluid Science 51 (2013): 271-278. https://doi.org/10.1016/i.expthermflusci.2013.08.009

[26] Chernysheva, M. A., S. I. Yushakova, and Y. F. Maydanik. "Effect of external factors on the operating characteristics of a copper-water loop heat pipe." International Journal of Heat and Mass Transfer 81 (2015): $297-304$. https://doi.org/10.1016/i.ijheatmasstransfer.2014.10.037

[27] Maydanik, Yury F., Vladimir G. Pastukhov, and Mariya A. Chernysheva. "Development and investigation of a miniature copper-acetone loop heat pipe with a flat evaporator." Journal of Electronics Cooling and Thermal Control 5, no. 04 (2015): 77-88. https://doi.org/10.4236/jectc.2015.54006

[28] Odagiri, Kimihide, and Hosei Nagano. "Heat transfer characteristics of flat evaporator loop heat pipe under high heat flux condition with different orientations." Applied Thermal Engineering 153 (2019): 828-836. https://doi.org/10.1016/j.applthermaleng.2019.02.022

[29] Chuang, Po-Ya Abel. "An Improved Steady-State Model Of Loop Heat Pipes Based On Experimental And Theoretical Analyses." PhD diss., The Pennsylvania State University, 2003.

[30] Furukawa, Masao. "Model-based method of theoretical design analysis of a loop heat pipe." Journal of Thermophysics and Heat Transfer 20, no. 1 (2006): 111-121. https://doi.org/10.2514/1.14675

[31] Adoni, Abhijit A., Amrit Ambirajan, V. S. Jasvanth, D. Kumar, Pradip Dutta, and K. Srinivasan. "Thermohydraulic modeling of capillary pumped loop and loop heat pipe." Journal of Thermophysics and Heat Transfer 21, no. 2 (2007): 410-421. https://doi.org/10.2514/1.26222

[32] Launay, Stéphane, Valérie Sartre, and Jocelyn Bonjour. "Analytical model for characterization of loop heat pipes." Journal of Thermophysics and Heat Transfer 22, no. 4 (2008): 623-631. https://doi.org/10.2514/1.37439

[33] Bai, Lizhan, Guiping Lin, Hongxing Zhang, and Dongsheng Wen. "Mathematical modeling of steady-state operation of a loop heat pipe." Applied Thermal Engineering 29, no. 13 (2009): 2643-2654. https://doi.org/10.1016/j.applthermaleng.2008.12.040

[34] Singh, Randeep, Aliakbar Akbarzadeh, Chris Dixon, and Masataka Mochizuki. "Theoretical modelling of miniature loop heat pipe." Heat and Mass Transfer 46, no. 2 (2009): 209-224.

[35] Chernysheva, Mariya A., and Yury F. Maydanik. "3D-model for heat and mass transfer simulation in flat evaporator of copper-water loop heat pipe." Applied Thermal Engineering $33 \quad$ (2012): 124-134. https://doi.org/10.1016/i.applthermaleng.2011.09.025

[36] Chernysheva, Mariya A., Vladimir G. Pastukhov, and Yury F. Maydanik. "Analysis of heat exchange in the compensation chamber of a loop heat pipe." Energy 55 (2013): $253-262$. https://doi.org/10.1016/j.energy.2013.04.014 
[37] Hamdan, Mohammad, and Emad Elnajjar. "Loop heat pipe: Simple thermodynamic." World Academy of Science, Engineering and Technology 52 (2009): 161-167. https://doi.org/10.1007/s00231-009-0555-0

[38] Ghajar, M., and J. Darabi. "Evaporative heat transfer analysis of a micro loop heat pipe with rectangular grooves." International Journal of Thermal Sciences 79 (2014): 51-59. https://doi.org/10.1016/j.ijthermalsci.2013.12.014

[39] Lin, Fang-Chou, Bing-Han Liu, Chi-Ting Huang, and Yau-Ming Chen. "Evaporative heat transfer model of a loop heat pipe with bidisperse wick structure." International Journal of Heat and Mass Transfer 54, no. 21-22 (2011): 46214629. https://doi.org/10.1016/i.ijheatmasstransfer.2011.06.015

[40] Siedel, Benjamin, Valérie Sartre, and Frédéric Lefèvre. "Numerical investigation of the thermohydraulic behaviour of a complete loop heat pipe." Applied Thermal Engineering 61, no. 2 (2013): 541-553. https://doi.org/10.1016/i.applthermaleng.2013.08.017

[41] Bai, Lizhan, Guiping Lin, Zuodong Mu, and Dongsheng Wen. "Theoretical analysis of steady-state performance of a loop heat pipe with a novel evaporator." Applied Thermal Engineering 64, no. 1-2 (2014): $233-241$. https://doi.org/10.1016/i.applthermaleng.2013.12.052

[42] Bai, Lizhan, Jinghui Guo, Guiping Lin, Jiang He, and Dongsheng Wen. "Steady-state modeling and analysis of a loop heat pipe under gravity-assisted operation." Applied Thermal Engineering 83 (2015): 88-97. https://doi.org/10.1016/i.applthermaleng.2015.03.014

[43] Zhu, Lin, and Jianlin Yu. "Simulation of steady-state operation of an ejector-assisted loop heat pipe with a flat evaporator for application in electronic cooling." Applied Thermal Engineering 95 (2016): 236-246. https://doi.org/10.1016/i.applthermaleng.2015.11.028

[44] Siedel, Benjamin, Valérie Sartre, and Frédéric Lefèvre. "Complete analytical model of a loop heat pipe with a flat evaporator." International Journal of Thermal Sciences $89 \quad$ (2015): $372-386$. https://doi.org/10.1016/j.ijthermalsci.2014.11.014

[45] Chernysheva, M. A., and Yu F. Maydanik. "Peculiarities of heat transfer in a flat disk-shaped evaporator of a loop heat pipe." International Journal of Heat and Mass Transfer 92 (2016): 1026-1033. https://doi.org/10.1016/i.ijheatmasstransfer.2015.08.108

[46] Esarte, J., A. Bernardini, J. M. Blanco, and R. Sancibrian. "Optimizing the design for a two-phase cooling loop heat pipe: Part A: Numerical model, validation and application to a case study." Applied Thermal Engineering 99 (2016): 892-904. https://doi.org/10.1016/i.applthermaleng.2016.01.150

[47] Weng, Chih-Yuan, and Tzong-Shyng Leu. "Two-phase flow pattern based theoretical study of loop heat pipes." Applied Thermal Engineering 98 (2016): 228-237. https://doi.org/10.1016/i.applthermaleng.2015.11.124

[48] Pozhilov, Aleksey A., Dmitri K. Zaitsev, Evgueni M. Smirnov, and Aleksander A. Smirnovsky. "Numerical simulation of heat and mass transfer in a 3D model of a loop heat pipe evaporator." St. Petersburg Polytechnical University Journal: Physics and Mathematics 3, no. 3 (2017): 210-217.

[49] Ramasamy, Navin Subbaiah, Prem Kumar, Bhimashankar Wangaskar, Sameer Khandekar, and Yuri F. Maydanik. "Miniature ammonia loop heat pipe for terrestrial applications: Experiments and modeling." International Journal of Thermal Sciences 124 (2018): 263-278. https://doi.org/10.1016/j.ijthermalsci.2017.10.018

[50] Li, Jian, Fangjun Hong, Rongjian Xie, and Ping Cheng. "Pore scale simulation of evaporation in a porous wick of a loop heat pipe flat evaporator using Lattice Boltzmann method." International Communications in Heat and Mass Transfer 102 (2019): 22-33. https://doi.org/10.1016/j.icheatmasstransfer.2019.01.008

[51] Chernysheva, M. A., and Y. F. Maydanik. "Simulation of heat and mass transfer in a cylindrical evaporator of a loop heat pipe." International Journal of Heat and Mass Transfer 131 (2019): $442-449$. https://doi.org/10.1016/i.ijheatmasstransfer.2018.11.034

[52] Gabsi, I., Samah Maalej, and Mohamed Chaker Zaghdoudi. "Thermal performance modeling of loop heat pipes with flat evaporator for electronics cooling." Microelectronics Reliability $84 \quad$ (2018): 37-47. https://doi.org/10.1016/i.microrel.2018.02.023

[53] Chernysheva, M. A., S. I. Yushakova, and Yu F. Maydanik. "Copper-water loop heat pipes for energy-efficient cooling systems of supercomputers." Energy 69 (2014): 534-542. https://doi.org/10.1016/i.energy.2014.03.048 